\title{
A Kingdom of Priests and its Earthen Altars in Exodus 19-24
}

\author{
Simeon Chavel \\ University of Chicago Divinity School \\ sbchavel@uchicago.edu
}

\begin{abstract}
This study analyzes the altar law in Exodus 20, the statement that frames it in Exodus 19, and its application in Exodus 24 as a single narrative that denies the professional configuration of sacrifice as essential to religion and divine blessing. It puts the gift-blessing exchange into the hands of every family, and reverses the basic trope of hosting-visiting and the social poetics that govern hierarchical religion: rather than host at his palace through mediating attendants, Yahweh visits wherever he is invited. The study argues that the narrative attacks an Israelian and Judean ideology in which royal success defines territorial extent, shapes the polity, enshrines divine power in temples, and controls divine blessing. It reconfigures the elements such that territory and nationhood are defined by the divine king, who roams freely throughout the land to bless each of his subjects, so long as they invite him to receive a gift.
\end{abstract}

\section{Keywords}

ritual innovation - pentateuchal criticism - kingdom of priests - earthen altar exodus 19-24

\section{Introduction}

This study aims to make a contribution to the study of ritual innovation and textuality, specifically ritual innovation in a text, with respect to the ancient socio-political entities of Israel and Judea and to literary works present in the 
Hebrew Bible. ${ }^{1}$ The study turns on a series of three linked texts: the so-called altar law in Exod 20:18-22, ${ }^{2}$ in which Israel's deity Yahweh expresses the desirability of multiple sites of worship; the statement of intent that frames and orients the law, in 19:3-8, in which Yahweh promises Israel will be a kingdom of priests; and the first, paradigmatic application of the altar law, in 24:3-8, in which Moses binds Israel and Yahweh in a covenant. The study argues that as the specific configuration of the altar prescribed in 20:18-22 does not in fact conform to any of the archaeologically or biblically known configurations of sacred space, sacred objects, concepts of divine presence and attention, and socio-political meaning, its author has drawn on several different configurations and lines of significance, reconfigured them in a new way, given the new configuration its own distinct religious meaning, and in the process advanced a bold political statement about the nature of Israel's nationhood. ${ }^{3}$ The related

1 This study has developed through several conference presentations: Political Hebraism: Jewish Sources in the History of Political Thought, Princeton University, September 7-9, 2008; Tikvah Project on Jewish Thought-Inaugural Seminar, Princeton University, November 17, 2008; Plenary Session: Pentateuchal Studies, The Fifteenth World Congress of Jewish Studies, Jerusalem, August 2-6, 2009; Special Program Unit: Ritual Innovation, Society of Biblical Literature International Meeting, St. Andrews, 7-11 July 2013; and in print: Chavel, "Biblical Law," 232-233, 238 n. 12. Applying Albertz's call to resist introducing dogmatic principles of division and selection (A History of Israelite Religion, 11), I use Ginsberg's term "Israelian" for the historical region and socio-political entity north of Judea to avoid the manifold confusion created by the biblical concept "Israelite" (The Israelian Heritage, 1-2), and "Judea/n" rather than the genealogical metaphor "Judah/ite" to avoid the presumption of categorical discontinuity between the periods of native monarchy and imperial satrapy.

2 The verse numbers 18-22 follow the so-called lower cantillation of the Decalogue, which divides statements 2 and 4 (idolatry and the sabbath) into several verses each and presents statements 6-9 (murder, adultery, theft, and false testimony) all as one single verse; this versification regularizes the verse-length throughout the Decalogue. The so-called upper cantillation makes each of the ten statements a single verse; this versification of the Decalogue conveys the ten statements. See the double set of cantillation marks in the Leningrad codex online: http://www.seforimonline.org/seforimdb/pdf/264.pdf, and see the separated sets in Dotan, $B H L, 109$ and 1227 , respectively. The verse numbers 22-26 (as in BHS) reflect a combination of the verse division of the lower cantillation at statements 2 and 4 and the verse division of the upper cantillation at statements 6-9.

3 On nationhood as a compound trope of family, territoriality, and duration; on the significant overlap between nationhood and religion; and on the validity and utility of the concept nationhood for analysis of the ancient world and as a concept in the ancient world, with particular consideration of the case of Israel, see, from the point of view political theory, Grosby, Biblical Ideas of Nationality, esp. 1-51, 69-91, 120-147, 191-212, 235-256. Of relevance for the argument below, it should be added that nationhood and kingdomhood, though different constructions of collectivity, are not of necessity mutually exclusive ones, much less antithetical ones: kings may claim to bring about and support nationhood and others may assess 
text in 19:3-8, which opens with distinctive language that also occurs in the opening of the altar law of 20:18-22, introduces the terms and concepts that establish the aims and the logic of the altar law. The other related text, in 24:3-8, provides an illustration of the concepts and the specifics of the prior two texts, while adding several new aspects, and these added aspects adapt yet additional practices - as construed from archaeological findings - to the argument of the texts. Key elements of the Deuteronomic corpus ${ }^{4}$ and of the Priestly History ${ }^{5}$ demonstrate that their authors encountered this string of texts within Exodus 19-24, understood its argument along the lines delineated in this study, and reacted to it in complex fashion, accepting some aspects and rejecting others as they constructed and advanced their own arguments around the same themes.

The study does not set out to advance a particular hypothesis about how best to explain the literary state of the Torah, namely, its incoherence as narrative and other difficulties. But a study of ritual innovation in a text must attend

them as having done so; the choice to promote one at the expense of the other is a political one-no less than the choice to blend them.

4 Use of the term "corpus" reflects the view that the text represents a secondary (probably 6th cent. BCE) collection of prior (chiefly 7 th cent.) materials sharing mindset, phraseology, setting, and form — not all of which the collector found complete and some of which the collector divided up to rearrange along formal and thematic lines (Haran, The Biblical Collection, 2:40-93). Use of the term also conveys that the materials do not constitute a narrative, only a series of discursively uncoordinated texts, specifically, several speeches and several discrete narratives. On narrative as the presentation of a sequence of causally linked actions (and story as an abstraction from narrative) see Rimmon-Kenan, Narrative Fiction, 1-28, also 86-105; for the useful concept of a spectrum of narrativity, see Simon-Shoshan, Stories of the Law, 1-22 (though he does not distinguish between story and narrative).

5 Use of the term "history" draws on and combines: (1) Huizinga's definition of history as "the intellectual form in which a civilization renders account to itself of its past," which recognizes: (a) the distance between the time and circumstances of the historian and those depicted in the work, (b) the implicit identification of the historian and his or her audience with the subjects of the historical work, and (c) the constructive nature of the historiographical endeavor ("A Definition of the Concept of History"); (2) White's characterization and categorization of the "history proper" or the "fully realized history" as having the form - the drama, completeness, and coherence — of fictional narrative ("The Value of Narrativity"); and (3) Herrnstein Smith's distinction between fictive and natural speech, according to which in the one the speaker and the audience share the presumption of engaging in a hypothetical world and in the other-this world (On the Margins of Discourse, esp. 3-75). A history, then, is speech (spoken or written) understood by (the speaker and) the audience to be about their real past (whether they accept its correctness or not), in terms that reflect matters of value in their present (whether in support or critique), and in the form of narrative that is uniquely suited to do so. (This definition can account for expository history and for third-party or secondorder historians too.) 
to the constitutive features of the text, namely, its framing and staging, and how those impact the meaning of the ritual presented in it. In this instance, the text presents itself as narrative - a narrative history - about Israel's formative past in which, among other things, Yahweh issued Israel instructions. In making a positive argument for the literary integrity of each of the three passages, for their interconnectedness within a single narrative text, and for that text with that narrative having preceded the Deuteronomic corpus and the Priestly History, the study departs sharply from a now long-productive approach that sees any or all of the three passages as variously reflective of and serially amplified by Deuteronomic, Priestly, and subsequent texts, concepts, and redactions and the historical conditions standing behind them. ${ }^{6}$ The study applies the kinds of assumptions of literary integrity and analyses of narrative continuity that lead to the view that the narrative of the Torah is best understood as the result of several separate works of narrative historiography having been spliced together (and joined with and further supplemented by additional materials). ${ }^{7}$

\section{The Altar Law in Exod 20:18-22}

The altar law in Exod 20:18-22 is a segment of a larger narrative. A third-person or external narrator speaks, and employs the signature wayyiqțōl verb-form

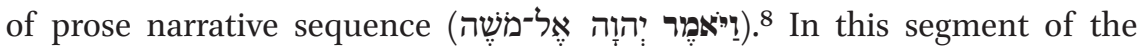

6 See the excellent analysis by Blum, Studien, 45-53, 91-99, 169-172; also SchwienhorstSchönberger, Das Bundesbuch, 284-299, 406-414; Kratz, The Composition of the Narrative Books, 133-140; Schmidt, "Israel und das Gesetz."

7 See Baden, J, E, and the Redaction of the Pentateuch, 153-161; idem, The Composition of the Pentateuch, 116-118; Stackert, A Prophet Like Moses, 75-77. Compare also Patrick, "The Covenant Code," 145-151. At the same time, this study diverges from just about all analyses and hypotheses by warranting the inference that the ("Elohistic") historical work that contained all three of the passages now in Exodus 19, 20, and 24 did not originally include Yahweh presenting his extensive set of laws, in 21:1-23:19 (or Moses transmitting them, in the relevant direct-object clause in 24:3); see below, n. 85. Note also my view that 20:1-13 too appears secondary (below, n. 57). Both additions seem to me essentially uninflected by Deuteronomic texts and concepts, and, as many have shown (e.g. Levinson, Deuteronomy; Baden, J, E, and the Redaction of the Pentateuch, 153-172), both appear to have made up a part of the Elohistic history by the time Deuteronomic authors engaged it.

8 For recent discussion of the nature and usage of this verb-form, and examples and possible principles of how it can serve to begin distinct units of narrative, see Joosten, The Verbal System, 161-192; Cohen, The Verbal Tense System, 24-27, 95-123, also 28-50. 
narrative, Yahweh speaks to Moses and instructs him to give the Israelites the

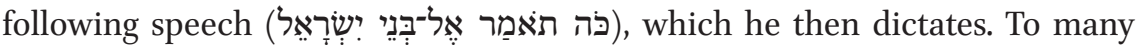
readers, the speech itself may sound a bit disjointed due to shifts in address, puzzling formulations, and a lack of explicit conceptual coordination and explanation of its different elements. Nonetheless, arguably it does comprise a single piece of discourse whose parts, in concert, make a coherent argument about Yahweh's ideal form of altar space. ${ }^{9}$

In this speech, Yahweh first instructs the Israelites to take mental note

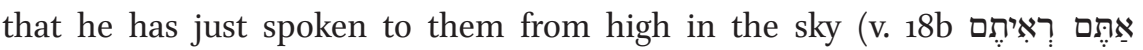

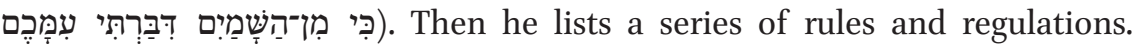
Attempting to infer any connection between the initial focalizing remark and the subsequent rules and regulations depends on having a clear sense of the idea that holds the rules and regulations together and animates them. Therefore, prior to such an attempt, we turn directly to the rules and regulations, a series of dos and don'ts.

From the aesthetic point of view, note that the prohibitive instructions, in vv. 19 and 21b-22, frame the positive ones, in vv. 20-21a (marked with red and green respectively in the chart below). This framing feature, which has an additional level (noted further below), provides second-order support for viewing the paragraph as a composed, coherent whole.

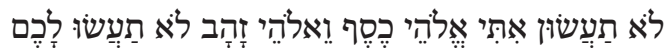

V. $20 a \alpha$

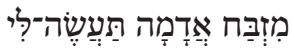

v. $20 a \beta$

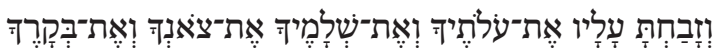

V. $20 b$

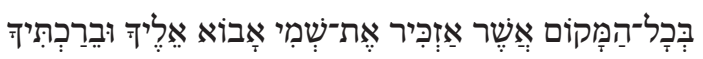

v. $21 \mathrm{a}$

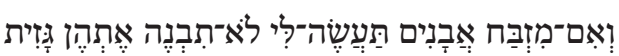

V. $21 b$

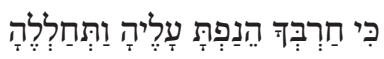

v. $22 \mathrm{a}$

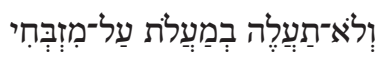
v. $22 \mathrm{~b}$

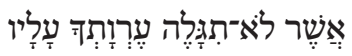

9 See Tigay, "The Presence of God," 195-199, who critiques the different arguments for an edited passage, but then calls the matter unsettled and settles for explaining the final form. Compare the maximal fusion of approaches in Childs, Exodus, 464-467. 
In terms of the substance, on the don'ts side, Yahweh prohibits gods of silver and gold, namely, sculpted images, which so often featured precious metals

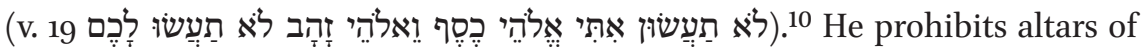

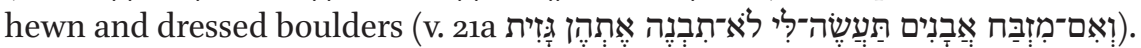

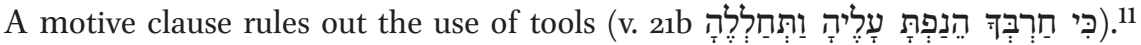

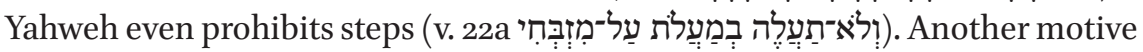

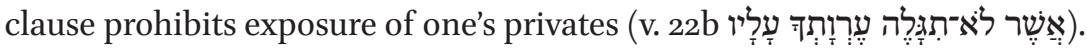

On the do's side, what does Yahweh want? Primarily, an altar made of earth

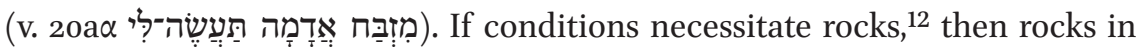

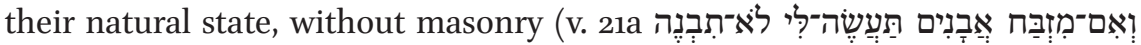

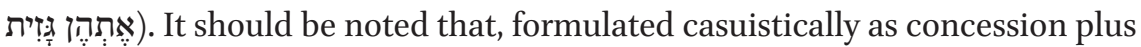

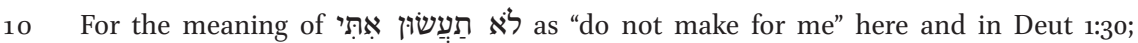
Judg 11:27, see Feder, "The Aniconic Tradition," 264 n. 51; already noted by Cassuto, Exodus, 177. Contrast especially the suggestion that the nature of the parallelism in the verse, along with the difficulty posed by the first clause, together recom-

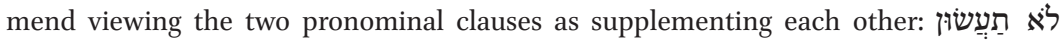

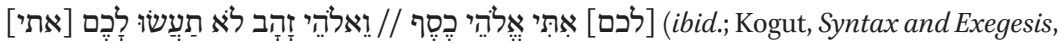
147-148).

That חֶר need not indicate a war-sword: Josh 5:2-3 (Dillmann, Exodus und Leviticus, 248). That Exod 20:21 has a stone-cutting tool in mind, see Deut 27:5; 1 Kgs 6:7 (see the discussion

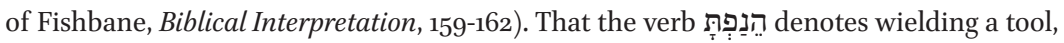

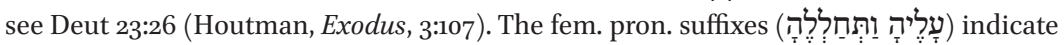

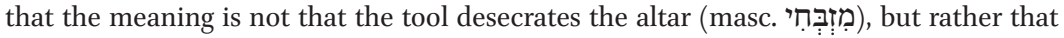

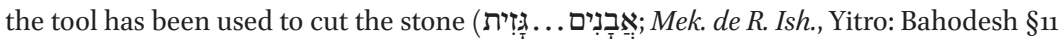
[ed. Horovitz-Rabin, 244 ll. 4-6]; Holzinger, Exodus, 81; Driver, Exodus, 208; Houtman, Exodus, 3:109; Wright, Inventing God's Law, 326). Telling is the contrast with SP, which has masc. pron. suffixes (עליו ותחללהו) so the clause refer to the altar (see also 1QExod frgs.

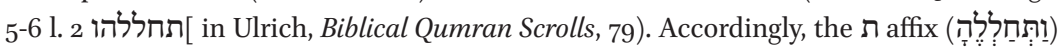
probably signals 3rd fem. and refers to the tool (fem. חֶרֶב), while in sp ותחללהו 2nd masc., namely, Yahweh's Israelite addressee. In possible double entendres, Mт Isa 51:9

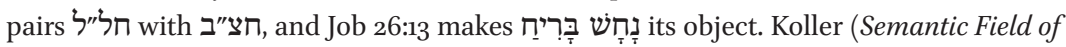
Cutting Tools, 162-217, esp. 168-177) argues that the term חֶר שֶרב denotes a single-axis cutting tool designed to cut animate objects $(168,213)$ or specific parts thereof $\left(177^{-178)}\right.$ including hair (205-206), and that its use in place of existing terms for subtypes, as in Ezek 5:1

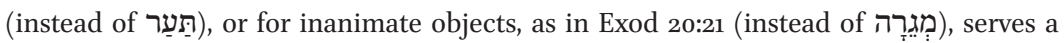
rhetorical, expressive function of calling to mind military associations (205-206, 210-211). However, Koller does not feel compelled to explain the use of צ' In Josh 5:2-3 this way (177-178), and the altar law of Exod 20:18-22 contains no other reflexes or signs of such an association, which makes it both unverifiable as intended by the text's author and unproductive as an element in the text. The first clear instance of the notion that to build an altar one's hands cannot be tainted with the blood of war occurs in 1 Chr 22:6-10; 28:1-3. So Cassuto, Exodus,178; Tigay, "The Presence of God," 195 n. 3. 
restriction, this last statement combines the acceptable (a "do") with the unacceptable (a "don't") and effects a transition from the dos to the don'ts.

From the aesthetic point of view again, these two varieties of an acceptable altar, the preferred kind in v. 20a $\alpha$ and the conceded kind in v. 21a, further frame the heart of the ritual envisioned, the volitional, reciprocal exchange of food-gift and food-blessing, in vv. 20a $\beta$-b (marked with green and blue below, respectively).

V. 19

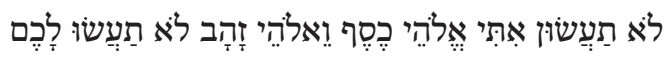

V. $20 a \alpha$

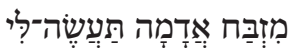

v. $20 a \beta$

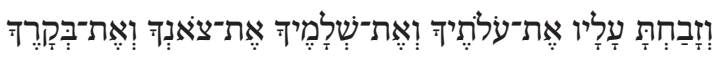

V. $20 \mathrm{~b}$

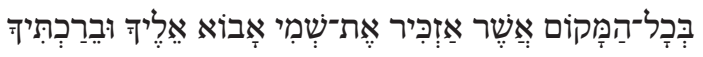

V. $21 \mathrm{a}$

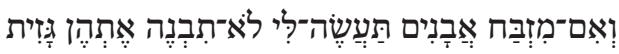

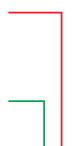

V. $21 b$

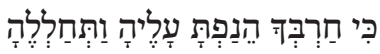

V. $22 \mathrm{a}$

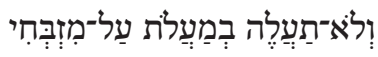
V. $22 b$

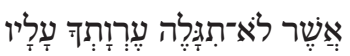

With respect to the food-gift, the earthen altar will serve both major types of gifts, the kind entirely burnt upon it and the kind shared between it and the giver, ${ }^{13}$ and gifts may come from both of the major classes of quintessential farming animals, the smaller and the larger (v. 20a

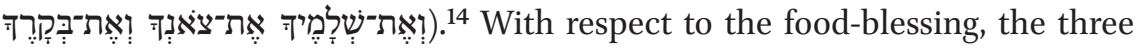
major text-traditions agree that Yahweh promises that every place he utters his name he will come and bless the giver (v. 2ob):15

\footnotetext{
13 So Cassuto, Exodus, 177.

14 Compare Levinson, "Is the Covenant Code," 299 n. 44.

15 In both мт and SP, the invocation clause is subordinate to the blessing clause that follows it, which makes the blessing a function of where the deity's name is uttered, but whereas мт expresses, distributively, that Yahweh's name will be uttered in many places (see Gen 20:13; Deut 11:24; e.g. Childs, Exodus, 447), sP במקום expresses there is only one such place. Five indications converge to point to sp here as a deliberate alignment with the centralized view of worship in Deuteronomy 12: (1) The opposition
} 


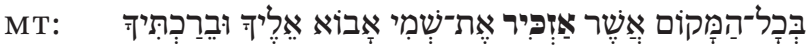

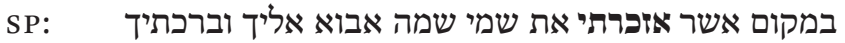

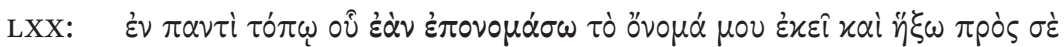

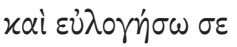 \\ ("at whichever place $I$ will utter my name there, and I will come to you and bless you")}

between the restrictive במקום "at the place" and the unrestrictive בכל המקום "at any

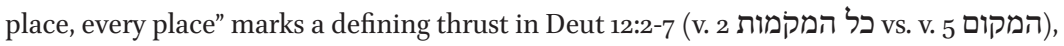

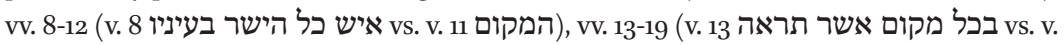

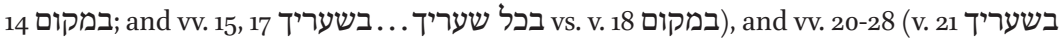

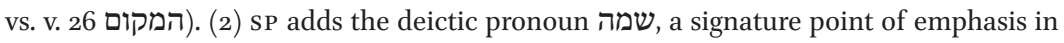
Deut 12:5, 6, 7, 11, 14. (3) SP formulates the object in the preceding offering clause with

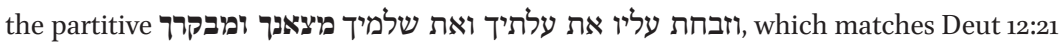
and presupposes its distinction between centralized sacred slaughter and local secular slaughter (see Levinson, Deuteronomy, 36-43). (4) SP generally draws elements of Deuteronomy into the other books of the Torah (see Tigay, "Conflation," 61-78; Tov, "Rewritten Bible Compositions," 339-351; Segal, "The Text of the Hebrew Bible," 10-17). (5) The ideological set of geographical elements unique to SP relies on the restrictive view of Deuteronomy: the added commandment in Exodus 20 to build Yahweh an altar at Mt. Gerizim; the systematic change of Deuteronomy's formula for Yahweh's select site, from one he will choose (мт: יבְחָר ) tבחר), i.e., in the addition at SP Exodus 20; and the related change of future אזכרתי in v. 20, which given the difficult syntax seems designed to have Yahweh refer to the altar of the added commandment, as if the essential clause is ("at the place I mentioned"-a few verses above) and the continuation את שמי שמה אזרי ("my name there") is essentially to be ignored (compare Tigay, "Conflation," 78-83, esp. 81; the suggestion that אזכמרתי could be taken to refer to Yahweh having caused Abram to call his name at Shechem in Gen 12:6-7 [Knoppers, Jews and Samaritans, 209-210] is unlikely since no manuscript has Abram doing so until Bethel, in v. 8).

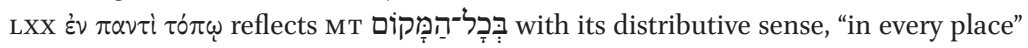

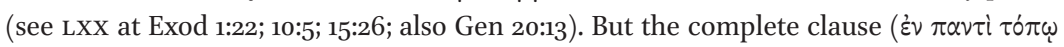

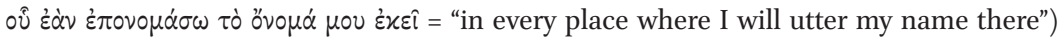

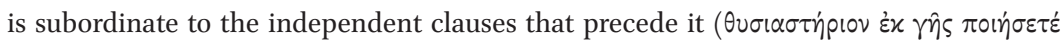

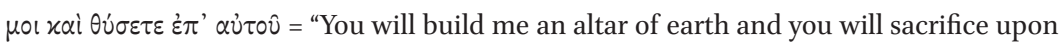

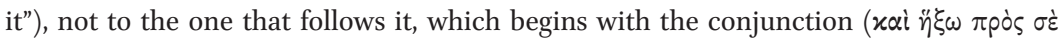

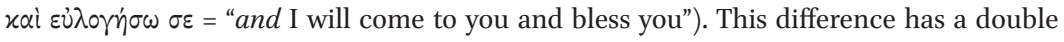
effect. It emphasizes sacrificing where Yahweh calls his name rather than on an earthen altar, and it makes Yahweh's arrival and blessing more exclusively a result of sacrificing where he calls his name, as if the text overall has Yahweh saying: "If you build an altar and sacrifice at the place where I call my name, then I will come bless you." Tigay notes that for MT to convey this sense, the site-clause should appear immediately after the initial materials-clause ("The Presence of God," 203). Deliberate assimilation to Deuteronomy is 
However, several considerations - not of uniform strength — lead to the recognition that Yahweh will come and bless wherever the giver utters his name:

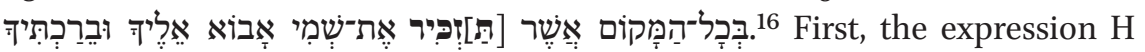

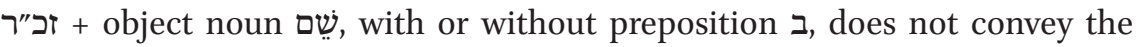
causative, "cause a name to be remembered," and certainly not the doubledup "cause a name to be uttered," but simply "to utter a name" (which has the effect of calling the referent to mind). ${ }^{17}$ Second, in the biblical idiom, whether

not clearcut. LXx does reflect the pronoun שמה and emphasize the place where Yahweh

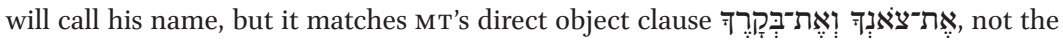
prepositional partitive מצאנך ומבקרך of Deuteronomy 12, and its rendering of the pivotal clause of v. $20 b \alpha$ suggests an immediate focus on the syntax and sense of the Hebrew rather than a concern to coordinate it with Deuteronomy 12. Compare Levinson, "Is the Covenant Code," 308-309.

In a distinctly interpretive rendering, Tg. Onq. contains elements present in SP and LXx (and in Mek. de R. Ish.) as well as its own non-literal elements, which together assimilate the formulation to Deuteronomy 12 and go beyond it to make the single-site meaning

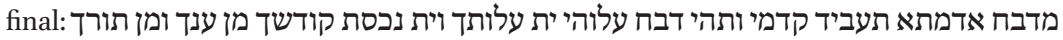
בכל אתר דאשרי שכינתי, לתמן אשלח ברכתי לך ואברכינד מודינד (ed. Sperber, 123). Tg. Ps.Jon. too represents several of these elements (ed. Rieder, 113), but see further below, n. 25 .

16 Contra Levinson, "Is the Covenant Code," 300-315. The three manuscript traditions of MT, SP, and LXX can agree yet still contain a secondary reading: Num 15:39 MT לִיִציצִ;

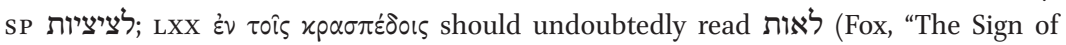
the Covenant," 569, 578-580). See Tov's critical review of principles and practices in the evaluation of readings, which he wryly boils down to "common sense" and an "art," and in conjectured emendations, regarding which he notes the randomness of preservation and rediscovery (Textual Criticism of the Hebrew Bible, 265-281, 327-340, esp. 270, 280-281, $329)$. For confusion between the letters $ת$ and $\boldsymbol{\aleph}$ in the old Hebrew script as a factor in the change of Exod 20:20, see Tigay, "The Presence of God," 204 n. 29 (for this problem in general, Tov, Textual Criticism of the Hebrew Bible, 228); the presence of the first-person formulation in SP, which has been copied continuously in the old Hebrew script, makes it nearly certain that the interchange took place in a copy in old Hebrew script. As an alternative, Tigay raises deliberate harmonization or assimilation ("The Presence of God," 204 n. 29). However, the recurrence of divine self-declaration throughout so much of the Torah-in all its sources-could easily predispose a copyist to expect the first-person form and to find it there, so to speak, when faced with graphic ambiguity; namely, the process need not have involved conscious exegesis as much as instinct. For the mentally complex nature of the production of some variants, see Tov, The Text-Critical Use of the Septuagint, 162-171 (on translators).

17 Namely, G זכבכ"ר = זכר = "have consciously in mind," while Her call to mind verbally; utter" (Ben Yehuda, Complete Dictionary, 3:1339b-1342a; H. Eising, "זָכָרָ", in TDOT, 4:64-82, esp. §§I.3, II.1, IV [65-67, 73-76]). Driver's complex reformulation illustrates well the problematic nature of the typical view: "they [i.e., such altars as these] might be 
human beings or deities do the uttering, the expression always refers to uttering someone else's name, never one's own. ${ }^{18}$ Third, it remains unclear what it would mean for Yahweh to utter his own name at a particular site, as opposed to having an object or site called by his name (N קרים + שִ + preposition

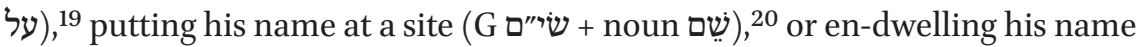

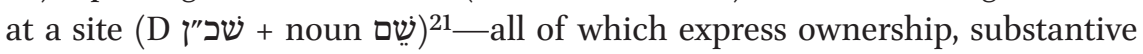
presence, or attentiveness; and nowhere does the expression H שִם noun refer to self-introduction. Fourth, given the intense concern of the authors of Deut 11:31-12:28 22 and other texts in the Deuteronomic corpus to restrict offerings and other interactions with the deity to a single site, and given their direct rejection of Exod 20:18-22 (and their adaptation of many related passages in 21:2-24:11), ${ }^{23}$ had 20:20 had the first-person verb, namely, an action by Yahweh with respect to his own name, one can expect those authors to have turned it

erected wherever Jehovah gave occasion for his name to be commemorated" (Exodus, 206). Explicitly, he assimilates the law to biblical depictions of patriarchal altars; see Gen 12:6-9; 13:14-18; 21:33; 22:1-18; 26:23-25; 28:10-22; 31:44-54; 33:18-19; 35:1-7, 9-15; 46:1-4; also Gen 8:20-21; 35:8, 16-20; Exod 17:8-16; 18:8-12 (207-208; see also Holzinger, Exodus, 80; Levinson, Deuteronomy, 31 n. 17; idem, "Is the Covenant Code," 98, 305 n. 55, 309-315; Houtman, Exodus, 3:102). In all this Driver closely follows Wellhausen, Prolegomena, 29-32. But one should rather acknowledge that those instances all differ from the pattern in Exod 20:18-22 of altar-building, invocation, meat manipulation, divine visit, and divine blessing. Other references to altars likewise differ from Exod 20:18-22. In some cases, the protagonist builds an altar in response to a manifestation of the deity: Judg 2:1-5; 6:11-32. Single-stone altars can serve simply to facilitate eating: Judg 13:15-23; 1 Sam 14:31-35. And some altars are built and sacrifices offered to bring about a favorable or desired result: 1 Sam 7:3-11; 2 Sam 24:15-25; also Num 22:41-23:3, 13-15, 27-30; possibly Judg 21:4. Recognizing the full range of depictions allows the configuration in Exod 20:18-22 to stand on its own. In all those cases where the narrator has the deity manifest himself, an altar is set up, but there is no sacrifice, Stockton suspects a secondary change from מזבח to ("Sacred Pillars in the Bible," 20).

18 So Tigay, ibid., 203; he only refers to worshippers, but also includes parallels in cognate languages from the regions around Israel and Judea.

19 See Deut 28:10; 2 Sam 6:2; 12:28; 1 Kgs 8:43; Jer 7:10, 11, 14, 30; 14:9; 15:16; 25:29; 32:34; 34:15; also Isa 63:19; see especially Isa 4:1.

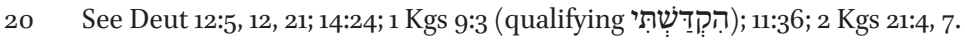

21 See Deut 21:11; 14:23; 16:2, 6, 11; 26:2; Jer 7:12.

22 On this unit of text beginning at Deut 11:31, not 12:1, see already Rashi, at 12:8; Bertholet, Deuteronomium, 38; esp. Rofé, "The Strata of the Law," 98-99. On its multiple authors, compositional history, and different impulses, concepts, and implications, see Chavel, "Deuteronomy 12."

23 See Ginsberg, The Israelian Heritage, 58-6o; Levinson, Deuteronomy; Chavel, "The Second Passover," 14-17, 21-22. 
directly to their advantage: * המקום אשר יבחר יהוה להזכיר שמו שם at least once. ${ }^{24}$ Finally, post-biblical traditions - predominantly by single-site supportersattest widespread irritation with the text as transmitted and resistance to it, actually anticipate the critical view, and thereby reinforce it. ${ }^{25}$

Taking a page out of Joseph's manual of dream analysis, one may say that together all the various prohibitions delineate one class of altar spaces, and together all the requirements and allowances comprise another. Archaeological finds from ancient Israel and Judea cannot explain these two classes-not because the ritual-space assemblages discovered violate the rules, but because they do not conform to the classes altogether. Regularly they mix some dos with some don'ts. Altars of whole stones and of hewn stones, steps leading to ritual surfaces, sites with no steps, niches suggesting sculptures, and a lack of such niches - all these occur in varied configurations. By the same token, in the narrative, Yahweh does not prescribe for all the artistically or positionally expressive items frequenting ritual sites that might index additional deities or otherwise affect the quality of his presence, like so-called standing stones, incense altars, stands for incense or other items, or model shrines; nor, for that matter, does he prescribe for the asherah of biblical and extra-biblical texts. ${ }^{26}$ The fact that the two classes in the text completely fail to align with the

24 Compare Tigay, “The Presence of God," 211 n. $5^{2 .}$

25 A passage in Mek. de R. Ish. voices a divine sentiment, "wherever my heart is, that is where my legs take me," and applies it as the principle of another teaching, that the deity can and will go "wherever": wherever ten gather to pray to him, citing Ps 82:1a; wherever three judge a case, citing Ps 82:1b; wherever two speak of him together (or judge a case?), citing Mal 3:16; and wherever one-the Ms cites Exod 20:20 אזכיר but the logic of the teaching requires תזכ-wherever one calls to him (Yitro: Bahodesh §11 [ed. Horovitz-Rabin, 403]).Tg. Neof. expresses this idea clearly and explicitly: בכל אתרא די תדכרון ית שמי בצלו "wherever you utter my name in prayer" (ed. Díez Macho, 2:133). Tg. Ps.Jon. cleverly has it both ways: בכל אתרא דאשרי שכינתי ואנת פלח קדמי "wherever I settle my presence and you pray before me" (ed. Rieder, 113). Others render simply: Tg. Frag. Ms V דתדכר בכל אתר די תד[כ]רו ית שמי קדישא (Maori, Peshitta, 82, with discussion); Tg. Sam. Ms A דתדכרות כרתרות (ed. Tal, 2:307).

26 For a detailed survey and discussion of the architecture, layout, and objects at sacred sites, see Zevit, The Religions of Ancient Israel, 123-274, 298-343 (217-218 for arguably charred remains of an asherah); Mierse, Temples and Sanctuaries, 58-155, also 156-227, 306-308, who provides lucidity in systematic attention to geography and chronology (if not in classification of sacred spaces and correlation with biblical terms, concepts, and historiography; his omission of Zevit's work is palpable and puzzling); Kamlah, Temple Building, in particular the articles by Mazzoni, Ji, and Daviau and the synthesis by Kamlah. The Priestly History appears to find a way to implicate incense offered by the individual, in Lev 9:24-10:2 and in the storyline at Num 16:4-7, 16-18, 35; 17:1-5, 11-15, evidently on the 
varieties of sites and assemblages recommends viewing the author as having deliberately selected specific elements of real-life configurations, on the basis of their idealized and stereotyped associations, in order to construct two new and opposing classes. To understand the two classes requires directly interpreting them, and doing so in a dialectical interplay between two factors: (1) the common denominator of each separate class and (2) the binary opposition between them.

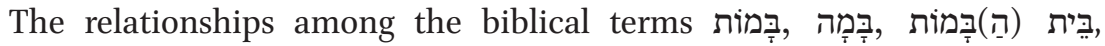

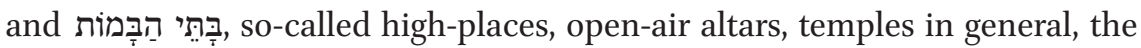
temple in Jerusalem in particular, and the sacred sites of Iron Age Canaan discovered have long proven difficult to establish. Scholars have generally drawn a significant distinction between high-places and open-air altars, on the one hand, and closed structures, temples, in particular the one in Jerusalem, on the other. ${ }^{27}$ Most implicitly and several explicitly identify the altar-type advanced

grounds that individuals will light it from a source other than the fire lit by the deity himself on the altar of his tabernacle; compare Haran, Temples and Temple-Service, 230-245.

Wellhausen uses the term בָָָּ "high place" inconsistently-first, following its sense in Amos and Hosea, to refer to any sacred site, including Jerusalem, then, slipping into the different sense in Kings, to refer to all sites apart from Jerusalem (Prolegomena, 23-27). Haran delineates four types and their distinct phenomenologies: [1] the temple: essentially a house for the deity's permanent residence (mainly in cities); [2] the lone, openair altar: essentially a site for slaughtering, which has no enduring divine presence; [3] the בָָָּ "high place" so-called (it could occur in a valley too): a developed subtype of the lone altar that has not clearly turned up among archaeological findings, because all such were destroyed; and [4] open sacred places or open cultic areas (mainly outside cities): marked by objects like pillars and sacred trees that might signify perpetual divine presence, often with altars, but without house-like features, practices, or conceptions (Temples and Temple-Service, 13-57). Tendentious biblical usage, he notes, applies "highplace" expressions to temples other than Jerusalem $(25,82)$. In categorically correlating altars (and, apparently, open cultic areas) with semi-nomads and temples with sedentary societies and in aligning them historically with pre-monarchic and monarchic Israel, Haran recapitulates the historical thought and schemes of (certain) biblical historiographers; moreover, he himself admits and even significantly develops the idea of the tabernacle as a temple of semi-nomads (17-18, esp. 189-204). He does not explain historically or phenomenologically why every temple would have an altar, why some temples might include open cultic areas, or practically how to distinguish a lone altar from an open cultic area with nothing but an altar. Barrick argues for the semantic opacity of biblical בָָָּ and its related idioms, maintains the gap between biblical terms and material finds, but emphasizes the biblical contextualization of the בָָָּ generally as built and urban, not a makeshift site on a hill and under verdant trees ( $A B D$ 3:196-200). Further in this direction,

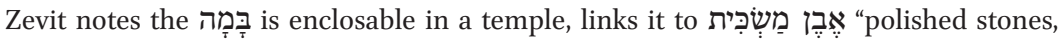

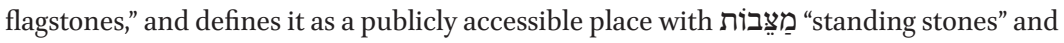


by Exod 20:18-22 as that of the high-place. ${ }^{28}$ However, to judge by archaeological findings, the metalworks, masonry, and steps prohibited in Exod 20:18-22 occur not only at temples but also at non-temple, open-air or less-fully builtup and less-fully enclosed sacred sites. Namely, the author of this passage has encompassed all the types of sites normally distinguished from each other as a single class. Authors in biblical literature hammer home repeatedly and material finds seem to agree that, in the minds of patrons, any of these sites ideally would house or hold some sculpture, and ideally such sculptures would feature a gold and silver overlay, if they were not made of them entirely. Such precious metals would give the sculpture that lustrous glow that signals its divine animation. Its shine may also serve to suggest a blinding aura that wards off unbefitting peeping. Because precious metals weather time well without decomposing - most obviously gold, but silver too after soap and a wiping glistens good as new- they may also convey divine immortality and undiminishing potency. Likewise, nothing conveys the permanence of an altar, its resistance to decomposition, as the largest, dressed stones that give it its smooth, weather-resistant, unfazed surface, which by extension, intimates the longevity of the deity present at the altar, served by it, and therefore in need of it to last. Ideally, a professional, largely permanent, largely hereditary staff would administer such a sacred compound, keep the masses outside the holiest confines, exclude them from the holiest of rites, and control the deity's very name and the blessing it yields. ${ }^{29}$

other objects indexing divine entities beside Yahweh-a type of cult corner at which actions like those at an altar took place, distinct from rural, region-serving, non-royal sites like "the Bull Site" and Mt. Ebal, "peak sanctuaries," evidently referred to by Hos 4:13; Ezek 6:13; 18:6ff. (Religions of Ancient Israel, 250-252, 262-263 [his self-differentiation from Haran seems imprecise and exaggerated]). Zevit's incisive comments on the disjunction between the etymology and morphology of מִזְבָּח "place of slaughter" and evidence that slaughter, skinning, and quartering precede placement on the altar, which serves for presenting the gift (278), show the severe limits of etymology for recovering signification and

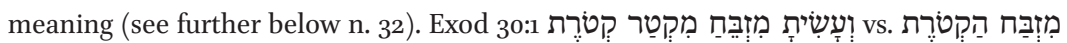
(v. 27; 31:8; 35:15; 37:25; also Lev 4:7) might register ancient awareness of the problem. The historical and phenomenological implications of this disjunction require separate treatment.

28 Alpert Nakhai, Archaeology and the Religions of Canaan and Israel, 49. At the same time, others correlate it with the altar at Arad (Mierse, Temples and Sanctuaries, 126), although enough typological analogues occur throughout the Levant to make any particularistic claim for Judea (and Israel) problematic.

29 Note Judg 17:1-13, in which Micah's sacred complex develops gradually. First, pieces of silver are made into a religious sculpture and placed in Micah's house (vv. 1-4). In a subse-

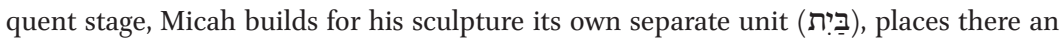


Now the stone quarries, masonry, transportation of goods, and assembly; the mining, procurement, and fashioning of precious metals; the purchasing, distribution, and training in the usage of tools; the administrative and performative staffing; the year-round coordination and maintenance of the entire system - all these manpower-intensive projects and endeavors typically require a complex network and a multi-tiered organization (or overlapping organizations) headed, or claimed to be headed, by a powerful figurewhether executive or symbolic_paradigmatically: a king. Accordingly, such religious compounds bespeak a king's control of the vast material world, of masses of human subjects, but also of the gods themselves. They demonstrate that the gods have blessed the king and that the king brings blessing to his lands. They intimate that the king cares for the gods and brings them pleasure. The manifold hierarchies defining this system mark the king as the pinnacle of human society, the sky-scraping conduit for divine blessing, the very nexus of the divine and human worlds. So do kings claim in so many ways, to varying degrees, in writing and in art, in the Levant as in Mesopotamia, and so do biblical texts repeat, whether in support or in critique. ${ }^{30}$

ephod and teraphim, and installs one of his sons as priest (v. 5). Finally, he attracts a Levite to take over the role permanently, which Micah takes as a sign of divine favor and a reason for joy (vv. 7-13). Namely, the episode represents an ancient perception of material success and religious structures as intertwined and also as on a dynamic continuum.

$30 \quad$ See e.g. Psalms 2; 21; 72; 89; 110; 122; 132; the monuments of Yehimilk, Mesha, Zakkur, Panamuwa (I), also Azitawada (Green, "I Undertook Great Works", 91, 99-110, 159-164, 177185, 237-248, also 307-315); Mierse, Temples and Sanctuaries, 7-8,149-150, 228-276, also 300-306 (though his effort to chart the spread of temple forms entails spending questionable time on David, Solomon, and Hiram in dubious, literary sources like Samuel-Kings, Chronicles, and Josephus). That remains of sacred sites of ancient Israel and Judea may not bespeak magnificence or immense power today or may not have done so to ancient neighbors has no bearing on whether local kings or comparable figures would have made powerful claims that seem to outstrip their accomplishments or on whether the claims would have had any purchase among their immediate audience. Though the rejection of sacred sites directly disenfranchises priests and many biblical passages target priests as corrupt and abusive (e.g. 1 Samuel 2; Hos 4:4-8; Micah 3), the emphasis in this text on the materials used to construct and furnish sacred sites and not on the activities there points to those responsible for construction and furnishing as the primary target of the text. In fact, all the assorted literature in the book of Kings uniformly, regularly, and systematically presents kings as responsible for, in control of, and accountable for temples and their riches (see also 2 Samuel 7-8; 24), and not only for their construction and maintenance but also for worship there, with priesthood subordinate to kingship and functioning within its system (see also Hosea 3-6; Amos 7; Zeph 1:2-9; esp. Ezek 43:7-9). Even the Priestly History has non-priests constructing the tabernacle and its furnishings- 
What the author of Exod 20:18-22 has Yahweh say he does want presents a wholly other kind of religious institution. Primarily, Yahweh wants an altar made entirely of earth, but if one must use stones, then stones in their natural state, untouched by the artisan's tool. Such an altar requires no special materials and no specialized human skills. ${ }^{31}$ Any person or small group of people can find dirt or stones and form a raised surface. The prohibition on steps helps ensure the altar never grow to imply a particular potency, exert a magnetic attraction on the families around, amass power and develop permanence. ${ }^{32}$

the chief artisan Bezalel of Judah, his second, Ohaliab of Dan, their anonymous corps of talent (Exod 31:1-11; 35:30-36:8), and their executive Moses (40:1-33). Varied significant challenges to reconstructing the economics of temple, of king, and of their relationship in the Iron Age Levant make it necessary and preferable to focus here on the ideological expressions found in the ancient literature (and non- or less-verbal mediums; see e.g. Caubet, "Art and Architecture in Canaan and Ancient Israel"). Compare Ahlström, Royal Administration; Manning and Morris, The Ancient Economy, esp. 1-88; differently: Sherratt, "The Mediterranean Economy;" Meyer, "Trade in Bronze Age and Iron Age Empires;" Master, "Institutions of Trade;" Steiner and Killebrew, The Oxford Handbook of the Archaeology of the Levant, 595-794, esp. 595-606, 677-682.

31 Note the striking contrast in the verse between general עש"ה "make" and specific and concrete בנ" עש"ה suild, construct," especially when in the context of metalworks in v. 19. Tigay notes how the uniform use of עשיה in the prohibitions on precious metals as well as the positive instructions regarding altars creates the sense that the altars stand in place of the sculptures ("The Presence of God," 203, further 204-205).

32 Zevit attempts to calculate the dimensions of a smaller altar of two or three steps and a workable altar with no steps ("The Earthen Altar Laws," 54-57; compare idem, Religions of Ancient Israel, 279-280). It is not clear that Exod 20:22 refers to this notion. To judge by the data (in the sources cited above, n. 26), Levantine sacred sites do not feature steps leading to the tops of altars but to platforms; altars are small enough that standing on them would be an awkward and even dangerous way to handle what burns there; and they are low enough that to stand beside them and reach with implements would be easier and safer. Given that animals were killed and quartered off the altar (once a fire burns?), the parts are easily tossed onto it with no need to stand on it. Indeed, the preposition על על מל here need not mean literally "on:" Judg 6:25-30 refers to the Asherah that is the altar of the Baal—hardly "upon" but "beside," "at," or loosely "above" (for potentially a related image of which, see fig. 46 and comments on it in Keel, "Paraphernalia of Jerusalem Sanctuaries," 324-325). The phrase על"ה על מזבח, then, might mean: to ascend a prepared, raised surface, a platform, so as to stand beside an altar on it; see 1 Kgs 12:32-13:6; 18:25-26; 2 Chr 1:3-6. Note the related expressions נצ"ב על מזבח in Amos 9:1 and נצ"ב על עולה Num 23:6, 17,

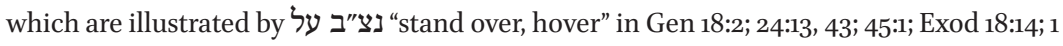
Sam 4:20; 19:20; 22:6-9; Ruth 2:5-6. Magnificence and an altar requiring steps are linked in the image of the future altar drawn by Yahweh for Ezekiel (Ezek 43:12-18), but that temple 
Easy to put up and relatively short-lived in nature, ${ }^{33}$ such an altar can stand, as

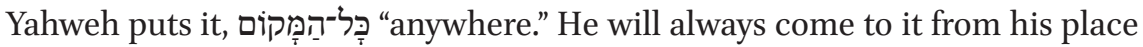
high in the sky, so long as one simply invite him to do so. By extension, should inclement weather or the wear of time wreck an altar, one can replace it, again, "anywhere." Yahweh promises always to come. Yahweh delimits the service of the altar: the kinds of animals ideally or paradigmatically found in every home and prepared with relative ease. A study in production simplicity and performative minimalism, such an altar requires no permanent dedicated personnel trained in secret rites to establish divine presence, perform its activities, cordon it off, or maintain it in the off-hours. Yahweh says nothing about an officiant class because the altar is entirely a family affair, and he promises to respond to each and every invitation, by each and every family, to bless them directly himself. ${ }^{34}$

From this point of view, one of the features of the paragraph that has struck scholars as anomalous ${ }^{35}$ may now fall into line as consistent, deliberate, and expressive. Yahweh begins his speech by addressing Israel in the second-per-

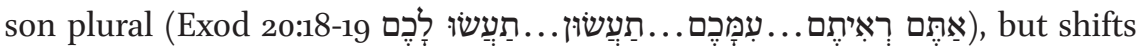

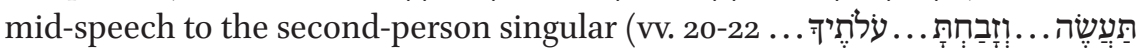

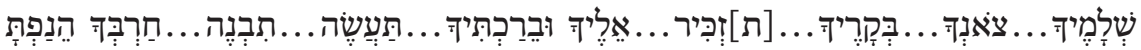
תַעְלֶה........ It would be consistent with the overall argument for the author to have Yahweh make this shift in address just as he shifts from the topic of metalworks to that of the earthen altar, precisely in order to signal and

must be understood to include non-Levantine, uniquely Babylonian features (Ganzel and Holtz, "Ezekiel's Temple").

33 So Wellhausen: "such an altar falls to pieces just as soon as it is built" (Prolegomena, 29; see too Holzinger, Exodus, 80), but then he goes on to list all the sites that according to the logic of the stories of the patriarchs have stood and served from the patriarchs until the time of the author and his audience (Prolegomena, 29-32).

34 The story centered on the altar at Mount Carmel, in which Elijah squares off against the devotees of Baal, in 1 Kings 18, has too many unique or ambiguous features to illuminate much. Among the complicating factors are (1) the plot-a one-time showdown between competing gods or between their respective advocates, (2) the ruined altar rebuilt by Elijah, which is presented as an identifiable site that one might wish to reuse, and (3) the invocation of the deities from below so they descend to their respective altars from above (the motif [noted by Stockton, "Stones at Worship," 74-75] of beseeching the deity to hear, on stones in cultic settings, may stand in the background of vv. 26-29). Taken all together, these features might show that less-developed, under-sponsored sites may not have claimed divine habitation, but rather divine visitation from above; at the same time, the ruined state of the altar may have signaled divine abandonment, hence the invocation and invitation.

35 Holzinger, Exodus, 8 o. 
to highlight the contrast between the large-scale collective and hierarchical effort involved in the production of high-end sculpture and architecture and the local control and simplicity of individuated household worship. ${ }^{36}$

\section{The Altar Law in Exod 20:18-22 and the Framing Introduction in Exod 19:3-6}

It warrants pointing out that the author's method for composing this lawneither in comprehensive detail nor in abstract principles, but by deploying terms and images paradigmatically and associatively for extrapolation by a knowing audience (be it whom it may) - this method matches that of the laws in the covenantal series that follows immediately upon this law, in chapters 21-23. ${ }^{37}$ In this instance, though, another narrative segment provides an explicit interpretive key, the earlier statement of intent in 19:3-6. Here too, the narrator narrates that Yahweh spoke to Moses, the narrator quotes Yahweh directly, and in the quote Yahweh instructs Moses to give the speech

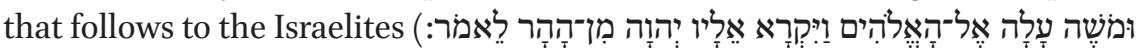

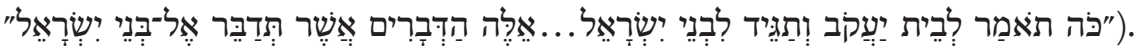
Significantly, the formulation of Yahweh's instruction here strongly resembles the one used by him to introduce his law about altars, in 20:18-22. In the entire

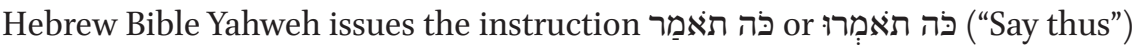
only eight more times; ${ }^{38}$ he does so with Israel as the addressee, only twice out of those eight—and those two instances occur within the same single

36 Darby's survey and analysis turn up the fact that biblical authors writing against religious statues chiefly concerned themselves with the statues' materials and manufacture, significantly less so their expressive, religious iconography ("Living in the Material World"). In the general direction of the socio-economic opposition identified in the above analysis, see already the comments of Ehrlich, who-far ahead of his time-dates the idea to the early Persian period, when Judea suffered poverty (Mikra Kifshuto, 1:174-175; Randglossen, 1:346). Compare the typical view of Driver, who thinks the law must precede the development of elaborate altars and the restriction of service to a designated priestly body (Exodus, 206). Böhl distinguishes suggestively between altars for simple offering and eating and large ones at established sanctified spaces, but then develops his interpretation of the passage in different directions, in part, as for Driver, due to its early provenance (Exodus, 151-152).

37 The clearest example: Exod 21:35-36; see Rashi. Further: Chavel, "Biblical Law," 240-247.

38 Exod 3:13-15 (twice); 2 Sam 7:8; 2 Kgs 22:16-18; Jer 27:4; 37:7; 45:4; Ezek 33:27. By other speakers, fewer than twenty more times. 
episode. ${ }^{39}$ And only in the statement in 19:3-6 and the altar law of 20:18-22 does Yahweh then begin his speech by calling the Israelites' attention to what they have recently experienced (אָתֶם רְִִיתֶם).

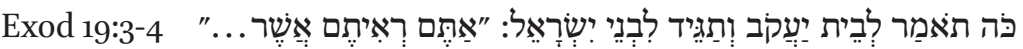

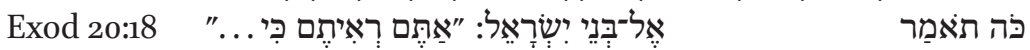

This unique correlation between the two segments signals through formal means the narrative continuity and conceptual link between them. ${ }^{40}$

In the speech itself in 19:4-6, Yahweh emphasizes several items of definitive importance: that the entire land belongs to him, that the entire nation will serve or wait on him as priests do, that they will constitute his kingdom, and that they will be holy, namely, worthy of proximity and access to him

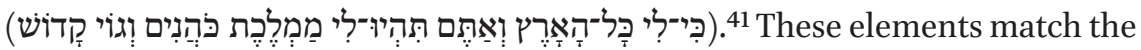
specifics of the altar law in 20:18-22. Yahweh is king, the entire land is his territory, Israel are his treasured subjects upon it. ${ }^{42}$ Wherever they be, they can use materials readily at hand to make an altar and issue him an invitation, and he will come and bless them. Neither a light unto the nations, nor intermediary on their behalf, nor even a nation of priestly levels of rules and regulationsas interpreted metaphorically in various permutations for millennia ${ }^{43}$ - the Israel envisioned in 19:3-6 is a nation of families each with direct, unrestricted access to the divine king. ${ }^{44}$ The altar law in 20:18-22 realizes Yahweh's concept

39 Exod 3:13-15.

40 Many have noted some of the formal similarities; none appear to have drawn substantive specific interpretive conclusions from them, e.g., Cassuto, Exodus, 176; Patrick, "The Covenant Code Source," 146-147; even Blum, Studien, 92 n. 207.

41 See especially Böhl, Exodus, 142.

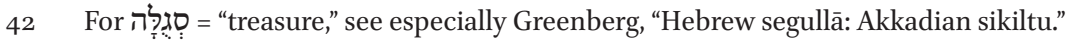

43 E.g. Sforno; Ehrlich, Mikra Kifshuto, 1:170; Holzinger, Exodus, 67; Randglossen, 1:337; Cassuto, Exodus, 156, Paul, Studies in the Book of the Covenant, 29-31; Childs, Exodus, 367; Houtman, Exodus, 2:445-446.

44 See Blum, Studien, 51-52. The prophecy in Isa 61:1-9, in the context of a series of prophecies recognizing the single temple of Jerusalem, seems directly to engage and adapt the ideas of Exod 19:3-6. It does not appear to predict literally that all Judeans will serve in the Jerusalem temple, but it does not shift the emphasis to the abstract notion of Israel's intermediation on behalf of the other nations either. To be precise, the prophecy envisions the thoroughgoing blessedness of the complete nation leading foreigners to consider them all an entire nation of priests, namely, enjoying divine proximity, service, and rewards. Compare Blum, ibid., 170-172. 


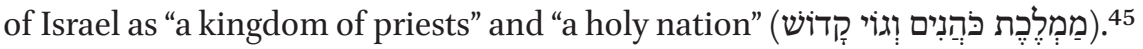
Reversing the traditional trope and its social poetics, Yahweh does not host Israel at his temples, aided by a permanent ministering class that mediates the approach. Rather, the Israelites host him, he happily comes as their guest, and they serve him directly. He waits for any and all invitations, always accepts, and never expects of his hosts or begrudges them what realistically they cannot provide. ${ }^{46}$

This view of these texts lends additional clarity and coherence to Yahweh's speech in Exod 20:18-22. Yahweh begins his speech by calling upon the Israelites to note that he has spoken to them from up in the sky (v. 18b

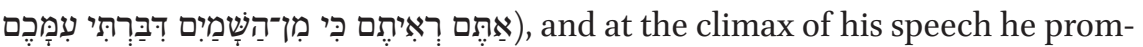
ises to come to them and bless them wherever they issue him an invitation

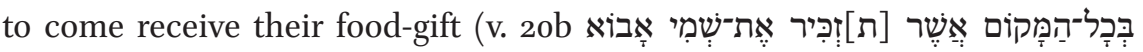

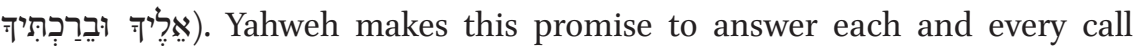
because, living in the sky, not embodied by sculpture, not ensconced in any

45 A passage in Mek. de R. Ish. offers the opinion that all Israelites were to have served as priests, but the golden calf episode led to the restriction of priesthood to Aaron and his progeny (Yitro: Bahodesh §2 [ed. Horovitz-Rabin, 209]) —an opinion that assumes that the golden calf episode preceded the commandments to set up a majestic tent administered only by Aaron and his offspring (so Rashi, but for unstated reasons). Houtman cites one understanding of the text as advancing the idea "that all Israelites, without distinction, like priests have access to God," he describes that view as one of a "universal priesthood of believers," and he denies it as "outside the horizon of Exod. 19;" in his view, the expression "kingdom of priests" means to emphasize "Israel's unique position as a people in its entirety" (Exodus, 2:446). The view developed above focuses not on universals, individuals, or believers, but on families within the nation, and the bound phrase "a

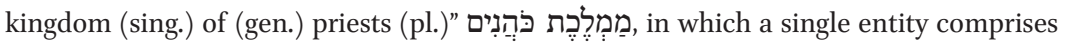
multiple elements of a uniform quality: a single kingdom made up of multiple priests, serves perfectly well to express and characterize the concept. Contrast also the view that the juxtaposition of clauses in 19:4 amounts to a parallelism and the parallelism requires

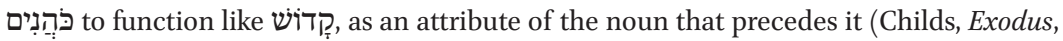
342 ), though a bound phrase of two nouns differs from apposition of noun and adjective precisely in the greater range of relationships that by its very design it can express.

46 Based on Driver's explicit comments at Exod 20:18-22 (Exodus, 206-209), when he remarks here, "a kingdom whose citizens are all priests, living wholly in God's service, and ever enjoying the right of access to Him" (171), he has in mind that Yahweh will manifest himself in various places throughout the land, in response to which Israelites may establish sites of worship at those specific places. 
earthly structure, free of the lock and key of king and keeper, he can. As he said

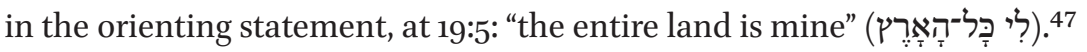

At first glance, in Exod 20:18 Yahweh's description of himself as having spoken to the Israelites from the sky might seem inconsistent with the narrator's prior description, according to which Moses ascends the mountain and Yahweh speaks to Moses there-literally, "from the mountain"

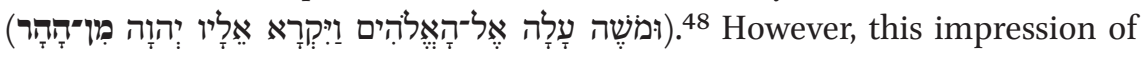
an inconsistency results from envisioning a low mountain with a visible peak upon which Moses and Yahweh meet, the two-dimensional triangle apprehended when one looks at a mountain from afar and so often depicted schematically in drawings. As anyone who has climbed a mountain can appreciate, one would do better here to envision a massive block, and in this case probably one of mythic proportions. It extends right up through the clouds, so that one cannot see its top or even sense just how far up it might be. ${ }^{49}$ Moses climbs the

47 For the whole of a territory as greater than the sum of its sacred-site parts, for the significance of such territory for nationhood, and for the political meaning of the term כִָּ "all, entire," see Grosby, Biblical Ideas of Nationality, 69-91, 120-165. It has long been taken for granted that the causal clause supports the statement that precedes it and claims that because Yahweh's domain encompasses the entire "earth" (whatever the appropriate cognate for ancient Israelians or Judeans would have been), he can select whatever nation he wishes for special treatment. However, there is no gainsaying the possibility that the subordinate clause supports the independent clauses that follow it and that the land referred to is specifically Canaan: "Because the entire land, i.e., Canaan, is mine, therefore you, i.e., all of you within it, will constitute a kingdom of priests and a holy nation." For examples of

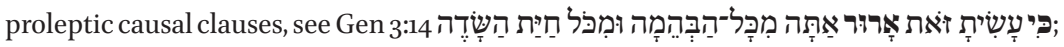

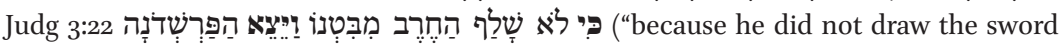
from his stomach, it [i.e., the insides of the stomach] came out the hole [i.e., the other

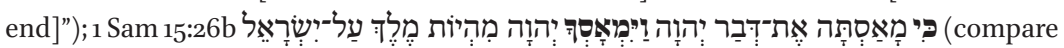

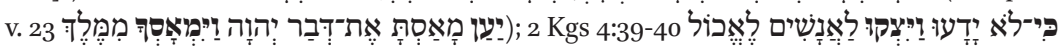
("because they [i.e. those serving] did not know, they put it out for the people to eat");

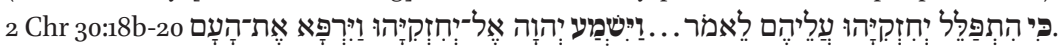

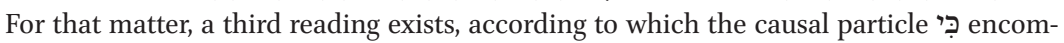
passes both following clauses; this reading sees a correspondence between fronted

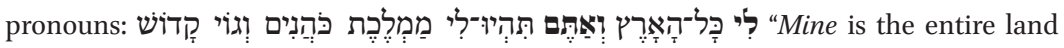
and you will be my kingdom of priests and holy nation." Compare Ehrlich, who sees the emphatic formulation "you will be etc., which stresses Israel's obligations to Yahweh, as balancing Yahweh's obligation to treat them specially among all the nations:

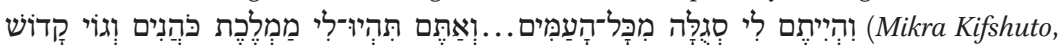
1:170; Randglossen, 1:337).

48 So Holzinger, Exodus, 79; Levinson, "Is the Covenant Code," 280.

49 Cassuto, Exodus, 176. Tigay considers this understanding "forced," but does not explain why (“The Presence of God," 199). Ibn Ezra, who from a traditional perspective addresses 
craggy base only so far. Yahweh speaks to him מִֹ־הָָה "from the mountain"from somewhere higher up on it..$^{50}$ Moses cannot see him. He can only hear him through the clouds. The syntax used to draw the scene-two sequential predicating clauses of alternating word-order: first, conjunction $w \bar{a} w+$ subject

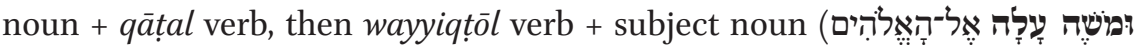

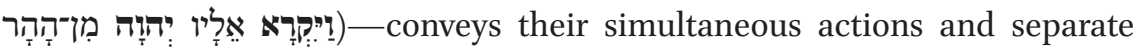
locations:51 "While Moses climbed towards the deity, Yahweh called to him from (somewhere up) the mountain."52

Consistent with this scenario, in the continuation of the narrative Yahweh informs Moses that he will descend to the level of the clouds so that the

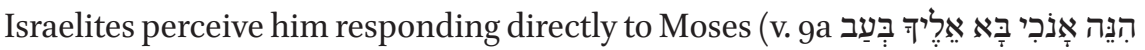

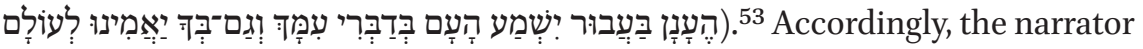
describes Moses bringing the people to the base of the mountain (v. 17), then

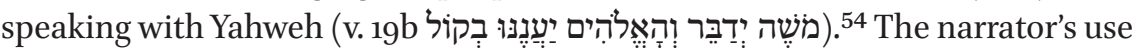

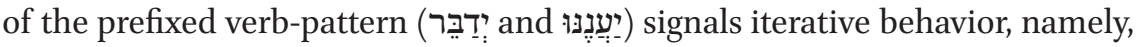
Moses prompted and Yahweh responded several times in a row: "Moses spoke (i.e. several times) and the deity responded to him audibly (i.e. each time)." ${ }^{n 5}$

the seeming contradiction with 19:20, resolves the matter by having recourse to the deity's representation as of great size: a manifestation like his feet is perceptibly lower on the mountain while a manifestation like his head, from which he speaks, is up in the sky (the so-called long commentary, at 20:18; see too Ramban; Sforno).

50 קרat peed not mean the abstraction "summoned" but can introduce direct speech and its contents, see Judg 9:7; Cassuto, Exodus, 155-156.

$5^{1} \quad$ See Talmon, "Synchroneity and Simultaneity," esp. 114-117, though he unnecessarily restricts his cases to those in which the same verb is used in both clauses.

$5^{2}$ Ehrlich, Randglossen, 1:336.

53 On the primarily teleological meaning of the root בו"א, see Koller, "The Semantics of לבוא." Contra Tigay, who attempts to gloss it as "be present" ("The Presence of God," 208) in order to support his argument that the altar symbolizes Yahweh's presence (205-209). Possibly, v. 9b contains an error and originally said that Moses informed the people of

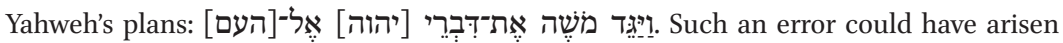
from the similar phrase in v. $8 \mathrm{~b}$ and from the continuation in v. 10, in which Yahweh speaks to Moses again; see next note. Compare Levinson, "Is the Covenant Code," 280-281 nn. 12, 13 .

54 That 19:19b fulfills v. 9, see Blum, Studien, 48-50, 71, though he views the texts as two blocs, vv. 10-19 and 20-25, the latter an expansion upon the former, whereas I see two interwoven narratives (not to be confused with two overlapping events in a single narrative), one in

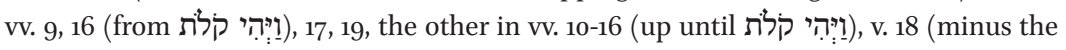
explanatory clause), and vv. 20-25.

55 Regarding ענ"ה "respond," compare 1 Kgs 18:36-39; regarding קול "something audible," compare 1 Sam 12:17-19. 
This repetition serves to persuade the people that they face no coincidence or trick but Moses engaging the deity in conversation face-to-face. ${ }^{56}$ It is this scenario that Yahweh has in mind and draws upon when he introduces the

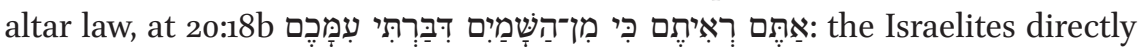
experienced him descending from his place in the sky to interact with them. Yahweh recalls this moment now because it establishes a definitive precedent ahead of the promise he is about to issue to descend and visit each and every Israelite who will invite him to do so. ${ }^{57}$

A third segment in the narrative provides an illustration of the altar law and of the concepts that animate it. The narrative episode in Exod 24:3-8, which con-

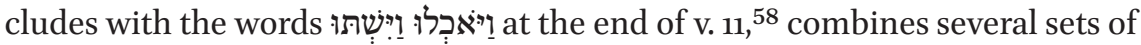

56 Compare Gen 41:32; Exod 4:1-9; Judg 6:36-40; 1 Sam 9:27-10:7.

57 Levinson notes the echo of 19:9 אבוֹא אֶלֶיף 20:20 ("Is the Covenant Code," 315). This reading, that 20:18 refers to 19:9 + 19, highlights Yahweh's self-initiated single speech in 20:1-13 as narratively inconsistent and likely an insertion (already Ramban felt 20:14-17 follows 19:18 or 19); indeed, the specific laws and ideas of vv. 18-22 provide the backdrop for the story of the golden calf (see below, n. 65; note already Haran, Temples

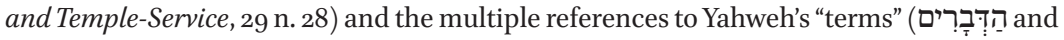

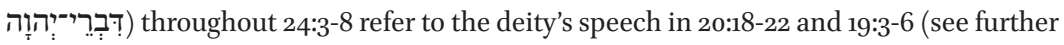
below). Compare Blum, Studien, 49-50, 93-97. In this case, the complement בִקוֹ 19:19 need not originally have referred to any distinct utterance, but to the unmistakable sound of speech, i.e., "audibly," or even to the signs of communication, i.e., "with thunder" (note

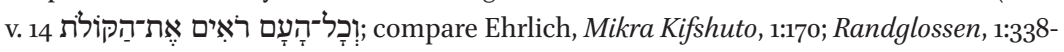
339). At the same time that this event in 19:9 + 19 serves as a precedent that the deity comes to individuals who call upon him—specifically, as he says in 20:18-20, those who make him an offering - it also establishes the pattern for the alternate form of interaction, oracular inquiry, as in 33:7-11 (on which see Haran, Temples and Temple-Service, 260275; Stackert, A Prophet Like Moses, 70-125, esp. 82-117).

$5^{8}$ That the eating and drinking in v. 11 refers to the offerings described in vv. 3-8, see Ibn Ezra (the so-called long commentary); Rashbam; Ramban; also Dillmann, Exodus und Leviticus, 288-289. Blum claims the Medievals made the connection because of the problem of Moses' unspecified location in v. 12, namely, they have Moses descend the mountain so Yahweh can summon him up again (Studien, 9o). This logic is nowhere apparent, implicit, or required in the commentaries, and Ramban explicitly lays out a different logic (the experience of divine presence must be celebrated through food and drink, and such celebratory food and drink must take place at an authorized site, in this case, the altar set up by Moses at the foot of the mountain). 
elements: from the statement of intent in 19:3-6 along with its continuation in vv. 7-8; from the altar law in 20:18-22; and also from the frame of the legal series in chapters 21-23. Importantly, the narrative keeps a neat distinction between Moses, who facilitates the covenant, and the sacrifices that attend it.

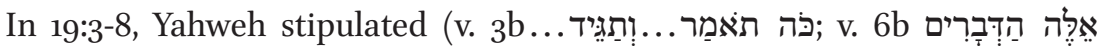

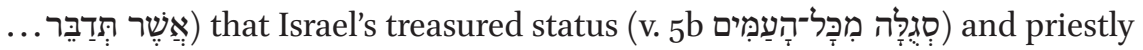

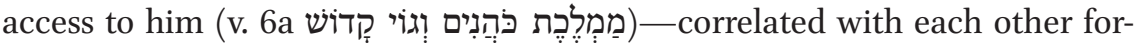

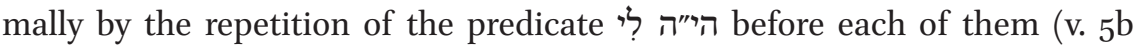

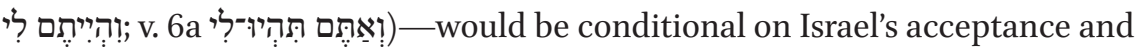

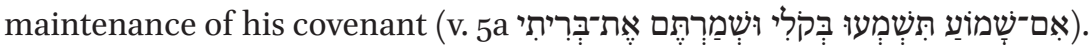

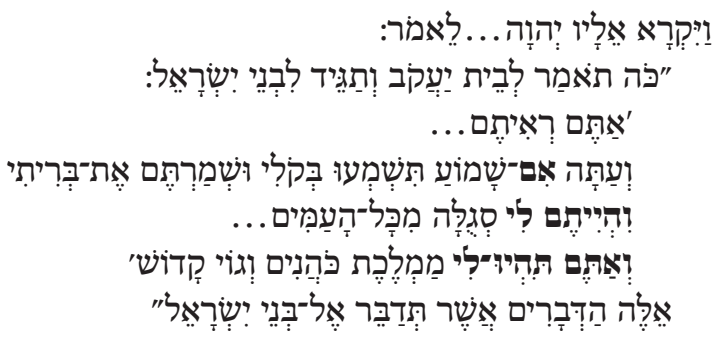

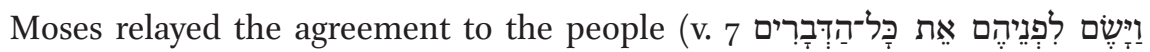

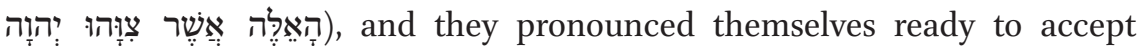

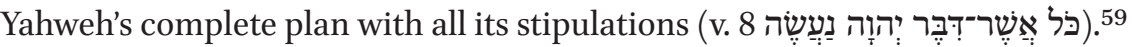

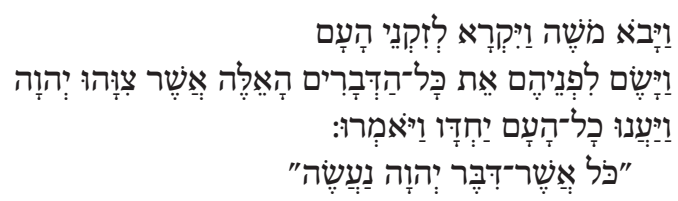

In the altar law of 20:18-22 and the laws and instructions in chapters 21-23, Yahweh detailed to Moses the specific stipulations of the covenant referred to

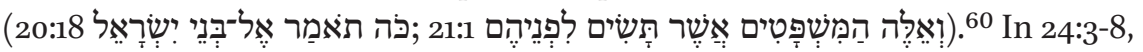

59 The narrator and Israel each echo a different part of Yahweh's concluding words to Moses.

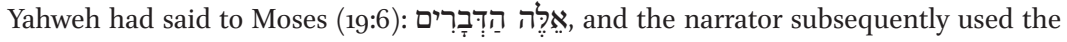

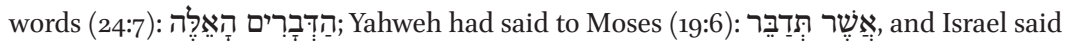

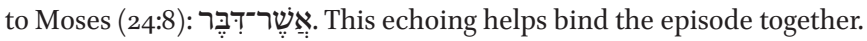

6o Again, echoes in diction bind the episodes together. The narrator had used the expres-

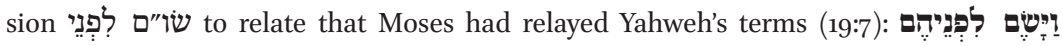

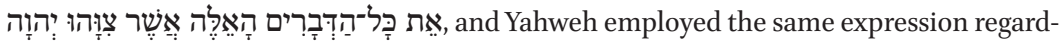
ing Moses' transmission of the specific rules by which the people should conduct their 
$11 b \beta$, in terms very similar to those in 19:3-9, Moses transmits those stipulations

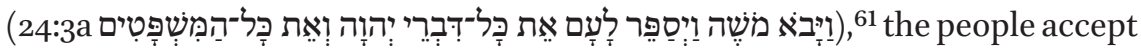

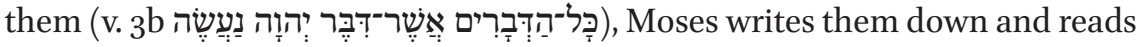

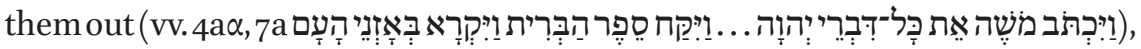

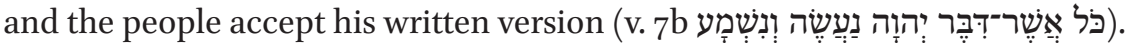

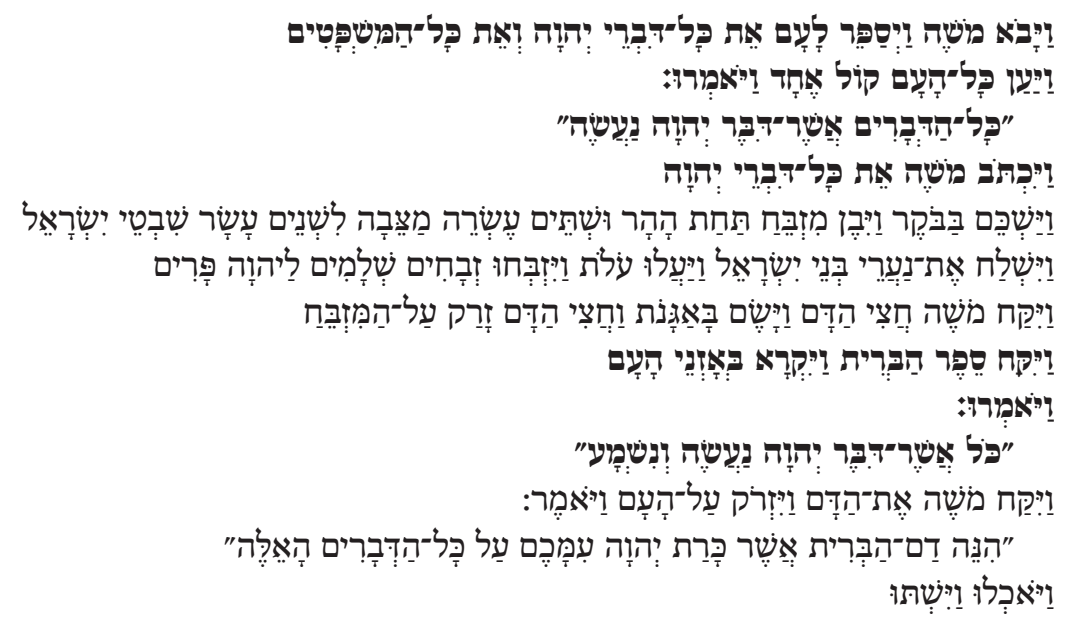

Moses solemnly marks the commencement of the covenant through ritual, and this ritual accords with the terms of the altar law in 20:18-22. ${ }^{62}$ Moses

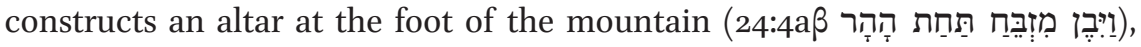
he commissions the youth of the Israelites - not a select, dedicated corps of

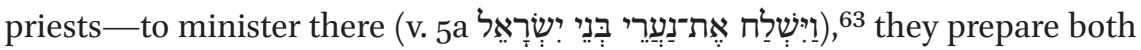

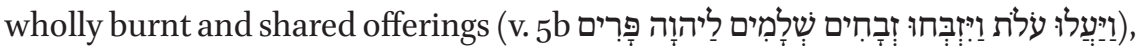

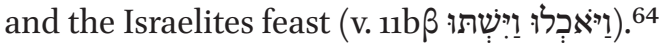

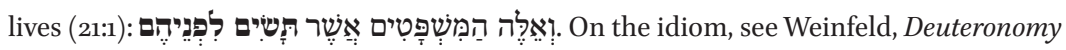
and the Deuteronomic School, 152-154. But on the relationship between these verses, see further below, n. 85 .

61 Cassuto, too, sees 24:3-4 as a reference specifically to 20:18-22 and 21:1-23:33 (Exodus, 217).

62 So already Cassuto, ibid.

63 Ehrlich confirms the emphasis put on Israelite youths (Mikra Kifshuto, 1:186; Randglossen, 1:362-363). Wellhausen links it to 20:22 (Prolegomena, 141). Blum connects it to the notion Israel as a kingdom of priests in 19:6 and emphasizes that the episode illustrates its concrete sense (Studien, 51-52). Note the contrast with Exodus 29; Leviticus 8, in which Moses prepares Aaron and his sons and initiates them into perpetual, hereditary service as Yahweh's priests.

64 Note the contrast with Lev 8:31-35. 


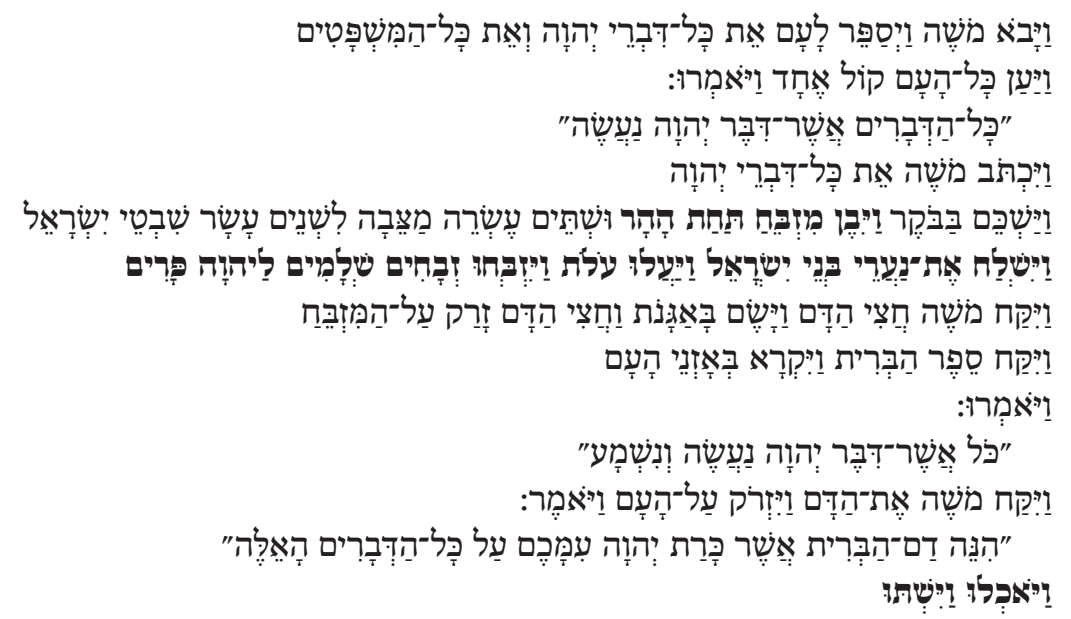

No one in this text, not the narrator and not any of the characters, gives the site a name or signals that it should live on in Israelite memory and practice as a place ever to return to, which anonymity and silence express the site's lack of inherent and enduring sanctity. ${ }^{65}$ Israel can always offer at new sites, just as

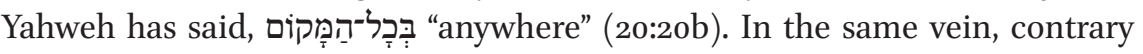
to other biblical traditions and their ritual systems, in which blood serves to index a circumscribed priesthood and its proximity and access to the deity, ${ }^{66}$ in the event depicted in $24: 3-8+11 b \beta$ Moses applies the blood to solemnifying

65 The "golden calf" episode further on in this narrative, in Exod 32:1-6, characterizes a sec-

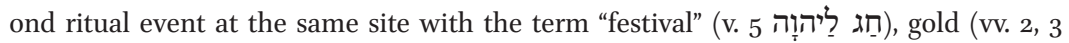

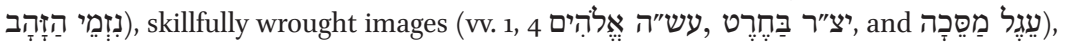

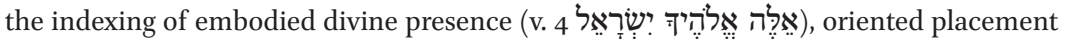

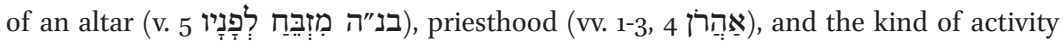

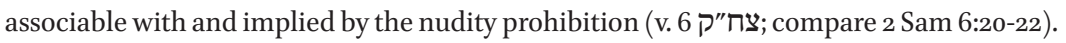
Compare Blum, Studien, 54. But note that Exod 32:1, 4 H על"ה differs from 20:2 H יצ"י איצ', and the sentiment of the statement overall corresponds to 19:4; namely, the episode in 32:1-6 does not show dependence on 20:1-13 and all its elements are accounted for without it (see above, n. 57). For the tradition of Aaron as the founding figure and representative of Israelite priesthood, see e.g. Exod 28:1; see also the narrative threaded through in 19:10$15,18,20-25 ; 24: 1-2$. For the classic statement of the argument that the golden-calf episode means to evoke and undercut Aaronide priesthood, see Cross, Canaanite Myth and Hebrew Epic, 195-215; compare Haran, Temples and Temple-Service, 84-92, esp. 90-92. Note also the similar story, in Judg 8:22-35, which features kingship, deluxe booty, and objects of divine presence-if in a different configuration and in a differently complex, composite text.

66 Note the contrast with Exod 29:10-12, 20-21; Lev 8:15, 17-19, 22-24, 30. 
the covenant-and not, for that matter, to the sanctification of all Israel as Yahweh's priests. ${ }^{67}$

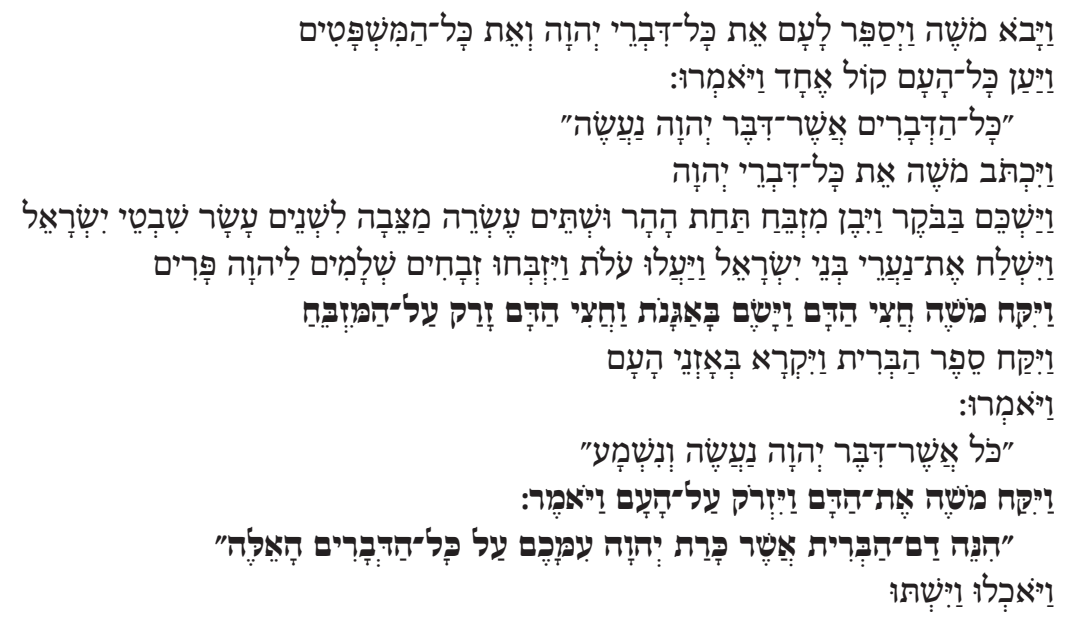

The anonymity of the site links up with yet another element in this segment of the narrative. Alongside the altar that Moses builds he positions twelve stones, one, explains the narrator, for each of the tribes of Israel $(24: 4 \mathrm{~b}$

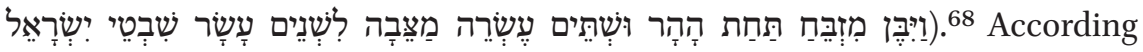

67 Contra Schmidt, "Israel und das Gesetz," 169-170, 181-183. It may be due to the pragmatics of Moses' single-handed management of the covenant and its rituals that the author has him build only one altar, rather than have every family build its own. This will be matched by Aaron building a single altar and a golden sculpture in Exod 32:1-8. Cassuto analyzes the complete configuration of the altar and the twelve stones as representing the two parties to the covenant, Yahweh and the tribes of Israel respectively (Exodus, 217). Accordingly, he suggests that just as Moses tosses part of the blood on the altar, he tosses the other part representatively on the twelve stones, not directly on the people (218; so too Stockton, "Stones at Worship," 59). Abusch emphasizes blood's ability to effect relations between god and human and exemplifies with this passage ("Blood in Israel and Mesopotamia," 677-678). Lewis draws on a variety of ancient Near Eastern and modern critical sources to argue that the use of blood in this text has multiple meanings, but he overlooks the artifice and argument of the text as narrative historiography ("Covenant and Blood Rituals").

68 Instead of мт מַעַבָ, which runs afoul of Lev 26:1 and Deut 16:22, SP has here אבנים. See Dillmann, Exodus und Leviticus, 286; Ehrlich, Randglossen, 1:362. In representing the twelve tribes of Israel, these stones differ completely from those put up by the patriarchs to mark divine presence whether of the uninvited kind, i.e., so-called "theophany" (Gen $\left.28: 16^{*}, 18,20-22 ; 35: 14-15\right)$ or the invited, i.e., as covenant witness and enforcer (31:44-54). See above n. 17 . 
to archaeological finds, Israelians and Judeans placed stones in their richly defined ritual spaces in ways that suggest specific individualized deities or divinized entities. ${ }^{69}$ They also placed stones out in the fields, with minimal to no distinct markers. If these field-stones were in fact sites to return to, then memory, lore and tradition alone would have to serve their contextualization. Among other things, such unmarked open-field stones can suggest ancestors, namely, family lineage and identity as a divinized entity characterized by collectivity and longevity. ${ }^{70}$ The author of the segment in Exod 24:3-8 + 11b $\beta$

69 There is no reason a priori to rule out the possibility that individuals placed family representatives at regional religious sites, whether they represented a collective or specific individuals, or, to put it differently, that regional religious sites had room for familial dimensions or expressions. The stone set up by Joshua in the temple of Yahweh at Shechem, in the narrative at Josh 24:26-27, seems a biblical adaptation of this practice (see further below, n. 73). For a review of the different roles stones might play, see Stockton, "Stones at Worship."

70 If Gen 31:52 and 53 come from a single continuous narrative, then the sequence suggests that the two sets of stones set up out in the open represent the two sets of divinized ancestors or family deities, whose immortality and inherent interest in one or the other of the parties make them ideal perpetual witnesses and arbitrators. Stockton notes that the abiding divine presence does not impact the sense of the deities' proper, fuller place elsewhere, in the same way that stones representing worshippers do not mitigate their real-life presence elsewhere ("Sacred Pillars in the Bible," 29-30, anticipating and serving somewhat to qualify Sommer, Bodies of God, 12-57). To describe such minimally marked stones as aniconic confuses artistry (the physical effort of preparation) with utility (the mental disposition and attitude of the users). Stones may show minimal effort at similitude, but, to the degree that they served representation, the people who selected, placed, positioned and acted around them considered them sufficiently, that is, fully iconic. One should not correlate iconography with iconicity (in the context of Greek art and religion see Gaifman, Aniconism in Greek Antiquity, esp. 3-6, 12-13), reduce forms of representation to the binary opposition of iconism and aniconism (which the distinction between de facto and programmatic does nothing to expand), confuse them with morphism (anthropo- or therio-) and reticence towards it, or focus one-dimensionally on visuality. Rather, one should distinguish (1) between explicit or direct representation, when an artifact — any artifact — stands in for the entity represented, be it a faceless stone or the most magnificent of humanoid statues, and implicit or indirect representation, when no artifact stands in for the represented entity but other artifacts or activities indicate its presence (like an empty throne-which must be considered anthropomorphism) and which may reflect any of various notions, from the irreducible, dissimilar otherness of the entity to the indignity of visual access; (2) between static representation, in which the entity is present or attentive constantly and uniformly, whether fully or not at all, and dramatic representation, in which human activity expresses a change; and (3) between artifactual representation, whether explicit or implicit, and verbal representation, which can 
appears to have adapted the idea of such faceless, collective-identity stones for the story of Israel's founding past and applied them to tribal affiliation, in other words, to the family writ large. ${ }^{71}$ Pointedly, the author did not have Moses put up a single stone for the single nation Israel, but twelve stones for the separate branches that together constitute it. ${ }^{2}$ This expression of collectivity in plurality, again, seems designed to resist the claim of kingship to singular embodiment, and to promote the nation as an entity apart from and preceding the state. ${ }^{73}$

Indeed, the fact that the altar law in 20:18-22 does not forbid standing stones, or for that matter wooden poles, an ephod, or teraphim, confirms that the narrative does not aim to purify Israelian and Judean religion per se on its way to philosophical monotheism or deism, but rather to wrest it from royal control and signification. ${ }^{74}$ The text is not about belief in Yahweh. It is about belief in

be: written on or near the artifact; spoken of or to the artifact or the entity represented by it; or written in a separate text, the content of which correlates or can be correlated with the artifact. Like the activities of dramatic representation, verbal representation can give explicitness to implicit representation or multiply the representative aspects of the artifact. Compare Mettinger, No Graven Image, 18-27, esp. 19-22 (in many respects preceded by Stockton, "Phoenician Cult Stones," esp. 1-3); Mettinger's aim to provide the phenomenological background out of which the Israelite prohibitions on images of the divine emerge (No Graven Image, 13-15) takes the prohibitions-considered anti-anthropomorphic aniconism - as the basis for conceptualizing that background, but taken together the prohibitions make too narrow and arguably too idiosyncratic a basis, and moreover they are uniform neither in concept nor in time.

71 Compare the memory-inducing event in Josh 4:1-8, in which twelve stones representing the twelve tribes (a national configuration) provoke children to ask their parents to explain them (a family configuration).

$7^{2}$ Right after discussing this passage, Abusch emphasizes, without recourse to it, that blood and sacrifice may effect the relation between the people ("Blood in Israel and Mesopotamia," 678-679). Lewis' survey seems to indicate he considers it an aspect of Exod 24:3-8 ("Covenant and Blood Rituals," esp. 343).

73 The single stone set up by Joshua at the temple of Yahweh at Shechem to monitor the Israelites' commitment and keep them ever mindful of it, in the narrative at Josh 24:26-27, seems a similar adaptation of divine-like stones to represent Israel, without the emphasis on the plurality of Israel. It would go too far afield to treat here the multiple points of contact between the narrative there and that in Exodus 19-24.

74 The possibility (which I have not read anywhere) that Exod 20:18-22 means to prohibit household statuettes and figurines made of silver or gold seemingly referenced in Isa 2:622 has several compounding weaknesses. First of all, archaeology has yet to turn up such items in Israel and Judea. Secondly, it is unclear what they have to do with the primary motif of the kingship of Yahweh in the running narrative within Exodus 19-24. Thirdly, household practices are not a main target of Exodus 19-24. Fourth, the paragraph in Exod 
kings. ${ }^{75}$ The author of this narrative series within Exodus 19-24 imagines - that is, constructs - the nationhood of Israel as a polity without the rallying point of muscular kingship or the pregnant institution of temple it patronizes. ${ }^{76}$

\section{$5 \quad$ The Argument of Exodus 19, 20 \& 24}

The string of related texts within Exodus 19-24, then, appears to be targeting an ideology according to which royal success defines territorial extent, gives shape to the polity, enshrines divine power in temples, and controls divine blessing. The narrative reconfigures these elements so that territory and nationhood are defined by the divine king, who roams freely throughout the land to bless each and every one of his subjects, so long as they keep his just,

20:18-22 highlights the domestic altar as the alternative to statues of silver and gold; were domestic figurines at issue, the discourse should have stressed a qualification of the ritual complex, not a replacement. Finally, meticulous analysis by Goldstein on Isa 2:6-22 concluded that especially vv. 20-21 but also vv. 7-8 are theologically polemical interpolations from much later periods ("Between Gods and Idols," 124-151), namely, they speak about religious practices of earlier periods stereotypically and affectively, not knowledgeably. Contra Holzinger, who severed the connection between the metals of v. 19 and the altar character of v. 20, and pitted the altar against stone monuments (Exodus, 80-81, 105-106); at the same time, he did note that the prohibition on steps contradicts Solomon's altar and that the prohibition on nudity stands against David's behavior in 2 Sam 6:14-23 (81). Contra also Zevit, who sees the text precluding worship of chthonic deities (Religions of Ancient Israel, 280-285). And contra Tigay, who argues that the text promotes the altar as the alternative to sculptures because it symbolizes the deity's presence, it does so aniconically, and it does so metonymically, as if there is divine residue from the visit ("The Presence of God," 205-209). In an important argument, Hendel draws a link between the opposition to sculpted and molten images and the opposition to kingship, but he locates this socio-political nexus in earliest Israel, which, on the basis of debatably early biblical texts, he conceives as having immense religious, political, and social coherence, a powerful ethos, and all the iconography and conceptualization of kingship minus the one element of direct anthropomorphic representation of the deity ("The Social Origins of the Aniconic Tradition," 378-382).

76 Instructively, the emphasis in Exod 23:23-25 seems to fall on prior installations for other deities. The idea that they are standing when Israel enters Canaan could indicate that the author means to signal the built-up kind of sites rejected in 19:1-8; 20:18-22; 24:3-8 + 11b $\beta$, not the makeshift kind promoted by the texts as ideal. Note that the passage does not mention the characteristics given particular prominence in Deut 12:3: wooden objects and worship upon every hill and under every verdant tree. For ancient images configuring significant stones and trees, see two 3rd and 4th cent. CE Tyrian coins in Stockton, though his discussion contextualizes them quite distantly (“Phoenician Cult Stones," 6, 10-13). 
edifying and sanctifying laws. It is in this spirit that the author has Yahweh establish his covenant with Israel and detail its terms in anticipation of Israel's entry to Canaan. No human king made Israel a nation by consolidating his control over Canaan. Yahweh made Israel a nation already on its way there by acts of possession, protection and presence. ${ }^{77}$

To judge by the historiographical material and the prophetic and the psalmodic collections of the Hebrew Bible, ${ }^{78}$ as well as a variety of literary and historical considerations, the kings who made such pressing claims in ancient Israel or Judea to which non-aligned Israelian and Judean authors might care to respond were neither Egyptian nor Canaanite, not Philistine or Assyrian; they were Israelian and Judean. And, so far as the rhetoric of the biblical texts conveys and historical and logical considerations dictate, these Israelian and Judean kings made their claims without polemicizing specifically against any prior traditions promoted by contemporaneous institutions. ${ }^{79}$ The narrative traced through Exodus 19-24 that resists the royal claim does not passively reflect a hoary, innate distinction between Israelite nationhood and that of all its neighbors around. Its author actively re-imagines nationhood from within, reconfiguring native regicentric models long entrenched in Israel and Judea as in the rest of the Levant. ${ }^{80}$

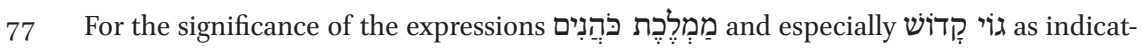
ing Israel's coherence and status as a polity, see Speiser, “'People' and 'Nation' of Israel." For the argument that Israel-Judea conceived itself as a nation apart from kingshipand first did so in the seventh century все, see Weinfeld, "The Awakening of National Consciousness."

$78 \quad$ E.g., Psalms 18; 21; 45; 78; 89; 110; 132; Isa 9:1-6; in its way, the pro-monarchic, pro-Davidic frame that holds together Judges-Samuel.

79 The competition of foreign kings did not take this direct form; it either made the local king directly responsible or dissolved the institution. Priestly houses mainly benefited from kingship. A so-called prophetic guild had no structures to manage a country; at best it could only critique (as highlighted well in Wilson, Prophecy and Society, with all its literary-critical and historical problems). If kings responded, as some Prophetic literature claims, it was to potential rabble-rousing - which only highlights the real target of royal propaganda: the masses it subjects and upon which it relies, whose local structures must be subordinated and coordinated.

8o Even if the author has drawn on a prior tradition of Israel as a multi-tribal entity, such a tradition itself is best engaged as having coalesced and crystallized with political force and direction as a response to the claims of kingship (whether at the strongest or weakest point in its fortunes requires argument). The author of the narrative within Exodus 19-24 develops the tribal tradition into a piece of historiography and adds the powerful political dimension of divine worship and covenant. For an important comparable, if not yet fully persuasive, argument regarding a different slice of biblical historiography, see 
The literature presented in the books of Amos and Hosea, dated to the eighth century вСЕ, offers three significant points of reference. First of all, passages in both books identify gold and silver sculptures and structures with royalty—chiefly Israelian but occasionally also Judean —and with priesthood and their abuse of the abusable (Amos 2:6-12; 3:9-15; 5:4-7, 21-27; 7:7-8:3; Hos $3: 4 ; 8: 1-14 ; 10: 1-8 ; 13: 10-11) .{ }^{81}$ Secondly, passages in neither book identify the matrix as Canaanite, though several in Hosea even call it Baalistic (2:4-22; 11:2; 13:1-11). ${ }^{82}$ Thirdly, passages in both books struggle to articulate nationhood

Rofé, "Ephraimite Versus Deuteronomistic History." Note an alternate biblical depiction of a qualified, negotiated kingship, in 2 Samuel 3; 5; 2 Kings 11 (compare Patrick, "The Covenant Code Source," 151-154), and its ancient analogue in Mari, as reconstructed in Fleming, Democracy's Ancient Ancestors.

81 Note in this context the arguably early text of limitations on kingship in Deut 17:16-17, $20 \mathrm{a} \alpha, \mathrm{b}$; the similar clustering in Isa 2:6-8; and the depiction of Solomon in 1 Kings 9-11each with its differences and each with its composition-historical problems.

82 One simply cannot assume that the historiographical and prophetic material in the Hebrew Bible speaks both knowledgeably and literally about Baal worship, and construct from it a history of Baal worship in ancient Israel and Judea. Taken all together, the sources present a picture with significant gaps and anomalies; weighed against each other, they offer quite different ideas of what the picture entailed. The depiction of Israel in Kings presents the Jehu dynasty of the late gth to early 8th cents. BCE as having successfully and enduringly eradicated the royally institutionalized Baal worship of the preceding Omri dynasty, which imported it from Phoenicia (1 Kgs 16:23-2 Kgs 17:6). The narrator's disquisition cataloguing Israel's history of offenses, which includes Baal worship, collapses the religious vicissitudes of the history into an essentialized view (17:723, on which see Goldstein, "The Composition of 2 Kings 17:7-23"). In the nick of time, Hezekiah presciently abolished from Judea the kinds of offenses about to lead to Israel's dissolution (18:1-6), but in Judea the specific offenses never included Baal worship until Judean royalty first took it up for a short period after Hezekiah, well over a century after Jehu, in the middle of the 7 th cent. (chs. 21-23). On the one hand, the narrator never remarks on the source of Judea's brief Baal worship; on the other, with historiographical consistency the narrator compares it to Ahab-since it will lead to the same result. Corresponding to the depiction of the Jehu dynasty - if not in fact among its sourcestexts attributed to Amos in the middle decades of the 8th cent. never charge Israel with Baal worship. Corresponding to the depiction of Judea in Kings, texts attributed to Micah and Isaiah in Judea in the late 8th and early 7 th cents. never charge Judea with Israelianinspired Baal worship, while texts attributed to Zephaniah in the decades after them lay one charge of Baal worship against Judea (1:4). As in Amos and Hosea, it associates it with built-up spaces, gold and silver, social exploitation, and geopolitical machinations (1:2-18, if it represents a single piece; compare Hos 2:4-15; 13:1-11), and does not call it "Canaanite" or Phoenician - or Israelian. Texts attributed to Jeremiah in the late 7 th and early 6th cents. - after Josiah's purge in 2 Kings 22-23 — highlight the charge of Baal worship (7:1-15; 
without king and temple. Their authors know no socio-political alternative, neither from their present, nor from historical precedent. They must doom the society in its entirety. Attempts to depict selective or partial destruction fail to get beyond mere numerical terms to a sociologically significant conception, and any revival envisioned either appears in politically unstructured, idealized terms, or includes Davidic kingship (Amos 9:8-14; Hos 2:11-24; 3:3-5; 11:8-11; 13:1-14:9). Namely, on the one hand, the argument advanced by the narrative within Exodus 19-24 has distinctive segmented correlations in material collected together and dated together as coherent; on the other hand, the argument synthesizes the parts into a view that goes beyond the set of correlations.

Finally, to judge by varied historiographical materials throughout the book of Kings and outside the Hebrew Bible, the author may also resent the metals and manpower appropriated and sent off to imperial powers by native kings aiming to maintain local hegemony. Yahweh, this author argues, makes and maintains Israel as a nation without the cost. On the contrary, advance

11:15-17 [Judea and Israel together]; 19:1-13 [compare 7:29-31]; 32:28-35 [compare 19:13]), but locate it at the ubiquitous illegitimate ritual spaces (e.g. 2:4-28 [compare 3:6-17, which like Hosea 4 does not mention Baal, and the Josianic dating of which accords with 2 Kings 22-23]; 11:11-13 [possibly a gloss]) and claim it to be a Judean tradition (9:12-13). Notably, the texts in Ezekiel offer a litany of Judean offenses for the same period as Jeremiah and never mention Baal worship. The lack of historical coordination among the sources, the discontinuity in the timeline and geography, and the strong thematic overlap in some sources alongside the stark differences between others-all these together suggest that at least some of the sources engage in rhetorical defamation and ideologically-informed historical speculation rather than reflect real practices and developments. Sources portraying Baal worship, traditions of ancient figures named for Baal (e.g. Jerubaal, Ishbaal, and Meribaal; see Tov, Textual Criticism of the Hebrew Bible, 247-248), and the fact that many sites throughout Israel and Judea are named for Baal (e.g. Baal Gad and Baal Hermon in the far north; Baal Hazor and Baal Tamar in the center; Baal Shalishah near Gilgal; Baal Perazim and Kiryat Baal in Judea; and Baalat Beer in the south) — any and all of these can have served Israelian and Judean authors in the construction of their past and even their present. Notably little "live" use of the name Baal has turned up in late Iron age Judea, whether in invocational texts, evocative texts, or personal names, especially in comparison with the name Yahweh (survey Ahituv, Echoes from the Distant Past; DobbsAllsopp, Hebrew Inscriptions; Avigad, Hebrew Bullae; Avigad and Sass, West Semitic Stamp Seals, esp. 489 s.v. bllhnn: "Hebrew Baal-names were common in northern Israel (Samaria ostraca 12, 27, 37), while none have been found in Judah"; and see Tigay, You Shall Have No Other Gods; Fowler, Theophoric Personal Names, 54-63, 338, 365-367). Compare Smith, The Early History of God, 65-107; Zevit, The Religions of Ancient Israel, 586-6o9, 648-652. 
additional texts, Yahweh freed Israel from captivity and bondage ${ }^{83}$ and gave them gold and silver! ${ }^{84}$

It bears considering that, in a sense, ritual innovation as effected in a text - the reconfiguration of known elements of religion in ways that express new ideas, but do not conform to past reality and may be fairly impractical, overly idealistic, or otherwise unrealistic to implement — can take good advantage of the genre of narrative historiography. So long as the author locates the idealized, expressive constructions in the past and has one of the characters, or several of them, articulate their viability for the future ever after, then the form of application by people in the author's own time need not match the terms of the text precisely. People able to affiliate themselves with a construction of ancestors and founders in the past can claim additional forms of continuity between themselves and the past in the text, such as ritual practice. Hermeneutics and other forms of bridging will do the work of filling in perceived gaps and eradicating perceived anomalies. ${ }^{85}$

83 Exod 19:4; 22:20 = 23:9; 23:15; also 20:2 (and 20:10, if Deut 5:14 indicates what once stood there); 32:1, 4, 7, 8, 11, 12, 23 .

84 Exod 3:21-22; 11:1-3; 12:35-36. But 32:2-4, 24, 31; 33:4-6 illustrate the pitfalls and ill-effects of that largesse.

85 This reading of the altar law of Exod 20:18-22, which strings it together with the introduction in 19:3-9, the application in 24:3-8 + 11b $\beta$, and the series of laws in 21:1-23:19, does face the challenge of explaining why the laws of slavery, homicide, theft, firstfruit and firstborn, and festival visits all mention fixed religious structures (21:5-6, 12-14; 22:6-8, 28-29; 23:14-19 respectively). Possibly, the inconsistency was meant to serve as deliberate misdirection on the part of an anxious author who cautiously built in "plausible deniability." Such a stance often characterizes a certain kind of revolutionary; see Strauss, Persecution and the Art of Writing. But identifying the historical circumstances of the composition depends on signs in the composition itself, which makes the explanation run the risk of circular reasoning. Alternatively, the inconsistency might reflect the author's use of existing material with minimal adaptation (along the lines of Patrick, "The Covenant Code Source," 154-157). However, it seems a problem to posit an author who works so intently on a topic of far-reaching consequences only then to undermine the argument rather unthinkingly; in narrative terms: the character Yahweh emphatically declares his interests in one direction, then advances their direct opposite, then says nothing when the people fulfill the first set. As yet a third possibility, the legal section of 21:1-23:19, which begins

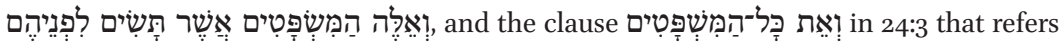
to it may have been added secondarily (compare Levinson, Deuteronomy, 153 n. 17; "Is the Covenant Code," 282-283). In 24:4, then, Moses would have written a short text (compare Cassuto, Exodus, 218), as in 17:14 (also with memorization and a commemorative altar) and in Deut 31:16-22 + 30; 32:1-44a. The Deuteronomic authors certainly made - that is, enjoined - extensive use of writing, memorization, and recitation of texts of varied 
Analysis indicates that the authors of both the Deuteronomic corpus and the Priestly History identified within Exodus 19-24 the ritual configuration and political agenda as delineated above and responded to it accordingly. Both sets of works champion the idea of a single ritual site or structure of divine choice and priestly control of that site or structure, and both react to Exodus 19-24 as a work that denies that structure, mediation, and hierarchy.

The Deuteronomic corpus cannibalizes Exod 19:3-6;20:18-22; and 24:3-8+11b $\beta$. Passages throughout the corpus co-opt the grandiloquent pronouncements

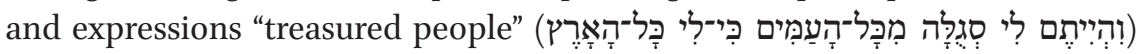
and "holy nation" (גוֹי קָדוֹש) featured in Exod 19:3-6,86 but they pointedly shun

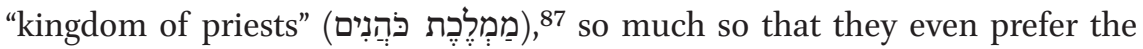

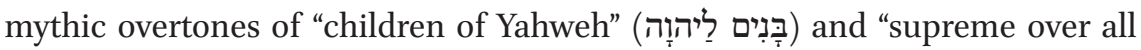

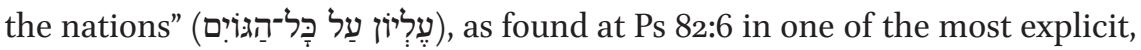
unapologetic biblical texts about the existence of additional deities of substance or standing: "I (i.e. El) had declared: 'You are divine!' and 'Sons of Elyon

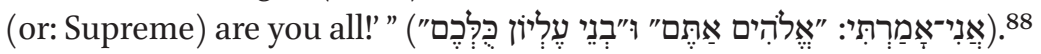

extent (Deut 31:9-13 + 24-29; also 6:6-9; 11:18-20; 17:18-19). In any case, the argument here inverts the point of ideological weight and polemical thrust in this narrative, from the law code to the persistently overlooked or subordinated paragraph on altar worship (see above, n. 57). Contrast Paul, Studies in the Book of the Covenant, 27-42, esp. 31-34; Patrick, "The Covenant Code Source;" Wright, Inventing God's Law, 11-14. That said, biblical materials attest a powerful and enduring ideology of Israelite kings and of Jerusalem as fonts of resolution, justice, and law, such that the inclusion of Exod 21:1-23:19 as part of Yahweh's covenant does continue the anti-royal thrust, even if somewhat differently.

86 So Patrick, "The Covenant Code Source," 155.

87 Contra Blum, Studien, 170.

88 As a hymn to Yahweh, the psalm replays (or: affords its performers the opportunity to replay) the moment when El declared to his audience that he hereby rescinds the divinity he had formerly granted them and appoints Yahweh to maintain the integrity of the entire earth. In this reading, the psalm expresses that gods other than Yahweh once existed but have since become mortal; El continues to exist, but, absent a host of immortals to manage, he has little purpose. The use of Elohim for Yahweh in Ps 82:1a, 8 belongs to a broader phenomenon in Psalms, on which see Joffe, "The Elohistic Psalter;" Ben-Dov, "The Elohistic Psalter." For extensive discussion of the problems interpreting Psalm 82, see Machinist, "How Gods Die, Biblically and Otherwise." For the relevance of Psalm 82 and Deut 32:8-12 to the Deuteronomic corpus, note Deut 4:19-20. 


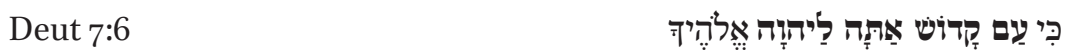

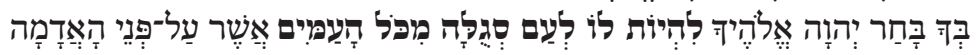

Deut 14:1-2

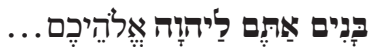

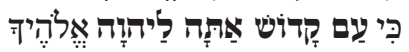

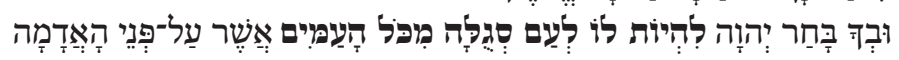

Deut 14:21

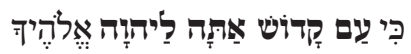

Deut 26:18-19

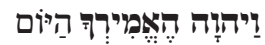

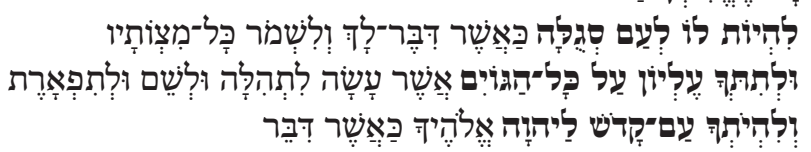

Deut 28:1

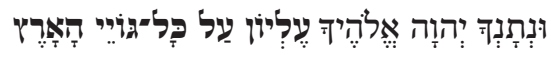

The key passage on centralization, in Deut 11:31-12:12, discredits the altar praxis of Exod 20:18-22 as an interim evil for Israel necessitated by the unsettled and unsecured conditions of life on the way to Canaan (Deut 12:8-12). Furthermore, the passage defames that altar praxis by associating it with the Canaanite practice of locating the names of their deities at enduring-type sites anywhere and everywhere (vv. 2-7) —an association triggered by juxtaposing the two sets of practice and by repeating the prohibition לא תַעַשוֹּן כ־ ("you shall not do as") in each one. ${ }^{89}$

89 Deut 11:31-12:12 effects its own reclassification of altar space. It lumps the temporary structures of Exodus 19-24 together with the fixed structures-here defamed as Canaanitethat would compete with the one single site chosen by Yahweh; see the parallel emphasis in vv. 5-7, 11-12. According to the historiography that includes 1 Kgs 14:23 and 2 Kgs 15:35; 16:4, Judeans failed this law, and according to 2 Kgs 17:10 so did Israelians. Deut 7:1-5, 23-26 and 16:21-22 seem focused on fixed installations in which alongside the altar (for Yahweh) stand any combination of wooden pole, stones, or sculptures, as in Josh 24:19-27 (Shechem); 2 Kgs 18:4 (Jerusalem); 23:15-16 (Bethel). Probably, the Deuteronomic authors found the idea of Exodus 19-24 horrific, but in practical terms less of a real threat than long-standing structures outside their chosen one. Arguably, Deut 12:13-28 contains several layers of text that successively accommodate the original Deuteronomic ritual innovation to its impracticability and result in further, unplanned, less-than-ideal innovations (see Chavel, "Deuteronomy 12"); allowing slaughter wherever and whenever looks quite like Exod 20:20-22, and insisting the blood be dumped unceremoniously on the ground may work precisely to counteract the potential implications of divine visitation. Compare 


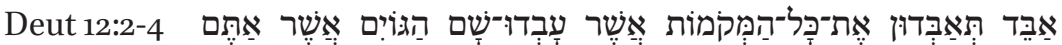

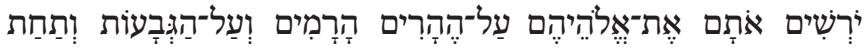

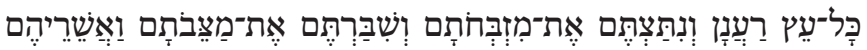

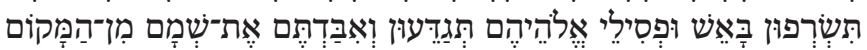

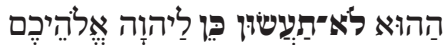

Destroy all the places where the nations whom you are dispossessing worshipped their gods, on the high mountains and on the hilltops and under every verdant tree. You shall demolish their altars and smash their standing-stones, and their 'ăšêrîm you shall incinerate, and the statues of their gods you shall hack to bits. You shall eradicate their name from that place. You shall not do so for Yahweh your god (i.e., as they did for their gods).

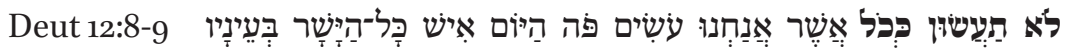

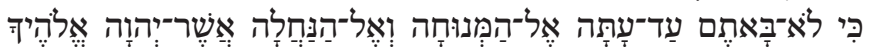

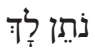

You shall not do like anything that we do here today, each one as he sees fit, (which is tolerated) because you have not yet come to the secure estate that Yahweh your god is giving you.

One of the foundational ceremonies for Israel to perform upon crossing the Jordan, in Deut 27:1-8, recasts the altar and stones of Exod 24:3-8 + 11b $\beta$ from paradigm and precedent to an exceptional one-time event. To avoid wielding tools (Deut 27:5; compare Exod 20:21b) Israel will build an altar of whole stones (Deut 27:6a; compare Exod 20:21a), and offer upon it wholly burnt and shared food-gifts (Deut 27:6b-7a; compare Exod 20:20a), but the

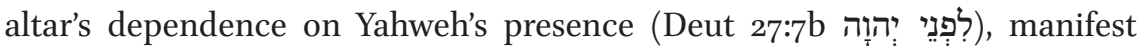
in the ark, ${ }^{90}$ guarantees that when Israel continues on in Canaan and the ark settles at Yahweh's chosen site, the altar will fall into disuse. ${ }^{91}$ Moreover,

Tigay's list of Deuteronomic texts that engage Exod 20:18-22 ("The Presence of God," 210-211).

$90 \quad$ See Deut 10:8; 12:7, 12, 18; 14:23, 26; 15:20; 16:11; 18:7.

91 Nothing in the text indicates that this site at Shechem is the one Yahweh has in mind. Moses never draws the connection and states that the instructions he received on Mt. Horeb about a place to be chosen and which he is relaying now in Moab for the first time 
standing next to it, a stone inscription-not a symbolic representative of Israel or its tribes but a text with Yahweh's instructions (compare Exod 24:12

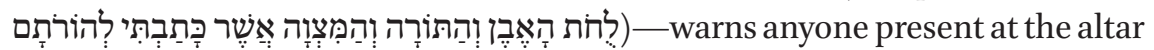

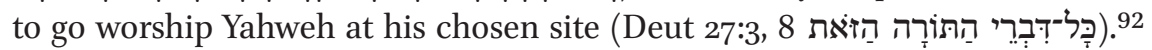
And the passage on the priestly Levites (Deut 18:1-8) replaces nationwide priestliness and its direct blessing with Yahweh's choice of a single site, priests proper, and their blessing. ${ }^{93}$

The Priestly History does not turn the narrative within Exodus 19-24 text for text, like the Deuteronomic corpus. Rather, it overturns its premise and narrates the history anew. Though this form of engagement makes the literary relationship harder to identify, the correlations in topics and points of emphasis suggest inspiration and reaction and warrant advancing the possibility. ${ }^{94}$ If the narrative in Exodus 19-24 located Yahweh in inaccessible regions to rob altar spaces of inherent holiness, dismiss their palatial quality, and nullify priestly mediation, the Priestly History - in Exodus 25-31; 35-40; Leviticus; Numbers 1-9-insists that one and only one such majestic structure exists, made in finery and maintained in solemnity; that Yahweh visibly inhabits it in all his holy glory (Exod 25:1-9;95 29:42-46; 40:34-38; Lev 9:2310:3; 16:1-3; Num 9:15-23); and that he determined every single tediously magnificent aspect of it, including the single-family priesthood that attends him

actually referred to Shechem. And the Deuteronomic corpus as a whole includes no texts in which Moses learns that from Yahweh now in Moab either.

92 Quite a debate exists about the compositional history and meaning of Deut 27:1-8. Compare Tigay, Deuteronomy, 486-488; Nelson, Deuteronomy, 316-318; Nihan, "The Torah between Samaria and Judah;" Schaper, "The 'Publication' of Legal Texts."

93 Also Deut 10:8-9 and 21:1-9, at v. 5, which, together with LXX and SP, indicate that in MT

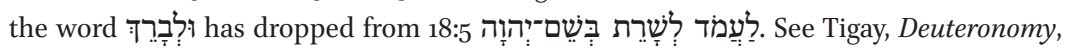
171, 375 n. 16.

94 A large set of secondary passages within the Priestly History-the so-called Holiness Code and distinctly aligned passages in Numbers - interacts with the laws of Exod 21:1-23:19 directly in a variety of ways (see Stackert, Rewriting the Torah, 31-164; Chavel, Oracular Law and Priestly Historiography, 48-57). There is no a priori reason to assume that the author of the initial priestly work, the historian, would not have known the narrative into which the text of Exod 21:1-23:19 was inserted and been moved by it to compose his own work of history, or that he would have had to engage it in the same manner by which the subsequent priestly writers engaged Exod 21:1-32:19. Pointedly, the character of Moses as prophetic founder of cultic forms and norms is unique to both Exodus 19-24 and the Priestly History (moreover, not just the Priestly historian but the author of Exodus 19-24 and aligned texts - namely, the Elohistic history - too may have advanced the idea that prophecy ended with Moses; see Stackert, A Prophet Like Moses, 70-125, also 168-190).

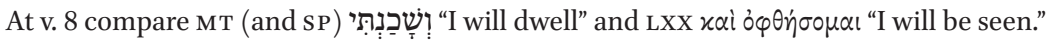


(Exod 28:1-3, 8-12, 15-21, 29-30, 36-38; also Numbers 16-18) and mediates his blessing (Lev 9:23-24; Num 6:22-27). So wondrous indeed are the architecture, interior design, furnishing and outfitting of the compound that Yahweh had to show Moses visible representations (Exod 25:9; also 25:40; 26:30; 27:8), and their construction required divinely skilled craftsmen (31:1-11; 35:30-35; also 28:3). Anyone who would offer gifts elsewhere, necessarily and by definition offers them to offensive, antithetical others, and does so at his peril (Lev 17:1-9). ${ }^{96}$

The authors of both works also repeat crucial parts of the argument of Exodus 19-24: Moses' foundational role, the troping of divine will and speech as law, Israel's unique chosenness, and making Israel's nationhood precede entry into Canaan and kingdomhood. ${ }^{97}$ Namely, they reject the attack on religious hierarchy as essential to divine space and ritual, but they embrace the attenuation of political hierarchy and the uniquely divine origin of Israel's nationhood. Accordingly, they cut the royal profile down to size, ${ }^{98}$ apply

96 Exod 28:42 prevents the self-exposure linked in 20:22 to a high or highly-placed altar. The implications are difficult to determine. First of all, there are grounds to view the statement in 28:42 as an interpolation (Nihan, From Priestly Torah to Pentateuch, $5^{2}$ n. 172), namely, a secondary harmonization rather than a concession original to the Priestly History (though Houtman's description [Exodus, 3:524] allows for authorial mishap, and Sarna [Exodus, 185] makes a compound argument for intent). Secondly, the compound

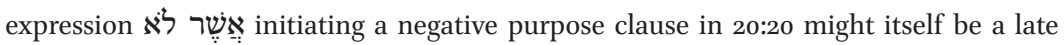
interpolation: a classical expression exists, פֶ: it seems an abbreviation of the longer

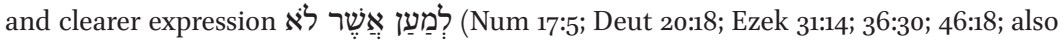
Gen 18:19; Lev 17:5; Deut 27:3; Josh 3:4; 2 Sam 13:5; Jer 42:6; Ezek 20:26); nearly all other instances are arguably characterization clauses ("such that"), which can refer to an effect and therefore can seem like purpose clauses (Gen 11:7; 2 Kgs 9:37; Jer 16:13); and the only unambiguous parallel is late: Qoh 7:21.

97 In this spirit, it suits the Priestly History to have the tabernacle settle at Shiloh (Josh 18:1; 19:51), a site in Canaan dissociated from kingship — according to received lore at the very least - by having existed entirely in the period preceding its rise (Judges 18-1 Samuel 13). Compare Haran's view of the Priestly History as a Jerusalem-oriented version of the foundation-story of the Shiloh-tabernacle, a view that entails rejecting all references to the Shiloh structure as a solid temple as mistaken anachronism (Temples and TempleService, 198-204); compare also his idea that the Priestly History registers a critique of the Jerusalem temple as falling short of the ideal (195 n. 14), though the ideal and the shortcoming are nowhere perceptible in the history.

98 In the Deuteronomic corpus: Deut 17:14-20. In the Priestly History, kingship appears explicitly but in general terms when Yahweh promises Abraham such numerous progeny that kings will issue from him, in Genesis 17 at vv. 6, 16; implicitly in the description of Joshua as martial "shepherd" in Num 27:15-23, at vv. 16-17; and possibly in the figure of the

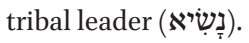


royal functions to Yahweh and the priests, ${ }^{99}$ and shift royal patronage to the people. ${ }^{100}$ Significantly, all three works establish Israel's imminent territoriality and define Israel's nationhood as requiring it. They attack nationhood's subjugation to kingship, not its territoriality. ${ }^{101}$

\section{$7 \quad$ Conclusion}

In sum, all three sets of texts-the narrative within Exodos 19-24, the Deuteronomic corpus, and the Priestly History-evince innovation in ritual configurations in the service of arguments about collectivity and hierarchy, religious and political. None can be taken either as a faithful reflection of ritual as practiced, or as a pristinely independent worldview.

\section{Bibliography: List of Abbreviations}

$A B D$

Freedman, David N. The Anchor Bible Dictionary. 6 vols. New York: Doubleday, 1992.

Abusch, "Blood in Israel and Mesopotamia"

Abusch, Tzvi. "Blood in Israel and Mesopotamia." Pages 675-684 in Emanuel-Studies in Hebrew Bible, Septuagint and Dead Sea Scrolls in Honor of Emanuel Tov. Ed. S.M. Paul and others. Leiden and Boston: Brill, 2003 .

Ahituv, Echoes from the Distant Past

Ahituv, Shmuel. Echoes from the Distant Past: Hebrew and Cognate Inscriptions from the Biblical Period. Trans. A.F. Rainey. Jerusalem: Carta, 2008.

99 In the Deuteronomic corpus: Deut 15:1-11, 12-18; 17:8-13; 31:10-13. In the Priestly History: Lev 25:8-19; Numbers 35 .

100 In the Deuteronomic corpus: Deut 16:16-17; 18:1-8; 26:1-15. In the Priestly History, e.g., Exod 25:1-9; 27:20-21; 30:11-16; 35:4-36:7; Lev 23:1-24:9; Numbers 7; 18; 28-29; 31 (even the Levites are the people's gift, in Num 8:1-19); it helps that the Israelites left Egypt loaded with livestock and goods (Exod 12:38).

101 There is nothing ideal about the wilderness; see Talmon, "The 'Desert Motif' in the Bible." As in the poem of Deut 32:1-43, it emphasizes a stage before creation, form, and order. 
Ahlström, Royal Administration

Ahlström, Gosta W. Royal Administration and National Religion in Ancient Palestine. Studies in the History of the Ancient Near East 1. Leiden: Brill, 1982.

Albertz, A History of Israelite Religion

Albertz, Rainer. A History of Israelite Religion in the Old Testament Period. 2 vols. Trans. J. Bowden. The Old Testament Library. Louisville, Kentucky: Westminster/John Knox Press, 1994. (Orig. pub. 1992 [German].)

Alpert Nakhai, Archaeology and the Religions of Canaan and Israel

Alpert Nakhai, Beth. Archaeology and the Religions of Canaan and Israel. Boston, Massachusetts: American Schools of Oriental Research, 2001.

Avigad, Hebrew Bullae

Avigad, Nahman. Hebrew Bullae from the Time of Jeremiah: Remnants of a Burnt Archive. Jerusalem: Israel Exploration Society, 1986.

Avigad and Sass, West Semitic Stamp Seals

Avigad, Nahman and Sass, Benjamin. Corpus of West Semitic Stamp Seals. Jerusalem: The Israel Academy of Sciences and Humanities; The Israel Exploration Society; The Institute of Archaeology, The Hebrew University of Jerusalem, 1997.

Baden, The Composition of the Pentateuch

Baden, Joel S. The Composition of the Pentateuch:Renewing the Documentary Hypothesis. New Haven and London: Yale University Press, 2012.

Baden, J, E, and the Redaction of the Pentateuch

Baden, Joel S. J, E, and the Redaction of the Pentateuch. Forschungen zum Alten Testament 68. Tübingen: Mohr Siebeck, 2009.

Ben Yehuda, Complete Dictionary

Ben Yehuda, Eliezer. A Complete Dictionary of Ancient and Modern Hebrew. 16 vols. Ed. H. Ben Yehuda, M.Z. Segal, and N.H. Tur-Sinai. Tel Aviv: La'am Publishing House, 1948-1959. [Hebrew] 
Ben-Dov, "The Elohistic Psalter"

Ben-Dov, Jonathan. "The Elohistic Psalter and the Writing of Divine Names at Qumran." Pages 79-104 in The Dead Sea Scrolls and Contemporary Culture: Proceedings of the International Conference Held at the Israel Museum, Jerusalem (July 6-8, 20o8). Ed. A.D. Roitman and others. Leiden: Brill, 2011.

Bertholet, Deuteronomium

Bertholet, Alfred. Deuteronomium. Freiburg: Mohr Siebeck, 1899.

Blum, Studien

Blum, Erhard. Studien zur Komposition des Pentateuch. Beiheft zur Zeitschrift für die alttestamentliche Wissenschaft 189. Berlin: de Gruyter, 1990.

Böhl, Exodus

Böhl, F.M. Th. Exodus. Groningen: J.B. Wolters, 1928.

Cassuto, Exodus

Cassuto, Umberto, A Commentary on the Book of Exodus. 3rd ed. Jerusalem: Magnes Press, 1959. (Orig. pub. 1942) [Hebrew]

Caubet, "Art and Architecture of Canaan and Ancient Israel"

Caubet, Annie. "Art and Architecture of Canaan and Ancient Israel." Pages 2671-2691 in Civilizations of the Ancient Near East. Vol. 4 of 4. Ed. Jack M. Sasson. Peabody, Massachusetts: Hendrickson, 200o. (Orig. pub. 1995)

Chavel, "Biblical Law"

Chavel, Simeon. "Biblical Law." Pages 227-272 in The Literature of the Hebrew Bible: Introductions and Studies. Vol. 1 of 2. Ed. Zipora Talshir. Jerusalem: Yad Ben-Zvi Press, 2011. [Hebrew]

Chavel, "Deuteronomy 12"

Chavel, Simeon. "The Literary Development of Deuteronomy 12: Between Religious Ideal and Social Reality." Pages 303-326 in The Pentateuch: International Perspectives on Current Research. Ed. T. Dozeman, K. Schmid, and B.J. Schwartz. Forschungen zum Alten Testament 78. Tübingen: Mohr Siebeck, 2011. 
Chavel, Oracular Law and Priestly Historiography

Chavel, Simeon. Oracular Law and Priestly Historiography in the Torah. Forschungen zum Alten Testament II 71. Tübingen: Mohr Siebeck, 2014.

Chavel, "The Second Passover"

Chavel, Simeon. "The Second Passover, Pilgrimage and the Centralized

Cult." Harvard Theological Review 102 (2009) 1-24.

Childs, Exodus

Childs, Brevard S. The Book of Exodus: A Critical, Theological Commentary. The Old Testament Library. Philadelphia: The Westminster Press, 1974.

Cohen, The Verbal Tense System

Cohen, Ohad. The Verbal Tense System in Late Biblical Hebrew Prose.

Trans. A. Aronsky. Harvard Semitic Studies 63. Winona Lake, Indiana:

Eisenbrauns, 2013 .

Cross, Canaanite Myth and Hebrew Epic

Cross, Frank M. Canaanite Myth and Hebrew Epic: Essays in the History of the Religion of Israel. Cambridge, Massachusetts: Harvard University Press, 1973 .

Darby, "Living in a Material World"

Darby, Erin. "Living in a Material World: Iconography, Idolatry, and Materiality in the Hebrew Bible." Society of Biblical Literature Annual Meeting, San Francisco, November 19-22, 2011.

Dillmann, Exodus und Leviticus

Dillmann, August. Die Bücher Exodus und Leviticus. 3rd ed. Ed. V. Ryssel. Leipzig: Hirzel, 1897.

Dobbs-Allsopp, Hebrew Inscriptions

Dobbs-Allsopp, F.W., and others. Hebrew Inscriptions: Texts from the Biblical Period of the Monarchy with Concordance. New Haven and London: Yale University Press, 2005.

Dotan, $B H L$

Dotan, Aron. Biblia Hebraica Leningradensia. Peabody, Massachusetts: Hendrickson, 2001. 
Driver, Exodus

Driver, Samuel R. The Book of Exodus. Cambridge Bible for Schools and Colleges. Cambridge: Cambridge University Press, 1911. Repr. 1953.

Ehrlich, Mikra Kifshuto

Ehrlich, Arnold B. Mikra Kifshuto. 3 vols. Berlin: M. Poppelauer, 1899-1901. [Hebrew]

Ehrlich, Randglossen

Ehrlich, Arnold B. Randglossen zur hebräischen Bibel: textkritisches, sprachliches und sachliches. 7 volumes. Leipzig: J.C. Hinrichs, 1908-1913. Repr. Hildesheim: Olms, 1968.

Feder, "The Aniconic Tradition"

Feder, Yitzhak. "The Aniconic Tradition, Deuteronomy 4, and the Politics of Israelite Identity." Journal of Biblical Literature 132 (2013) 251-274.

Fishbane, Biblical Interpretation

Fishbane, Michael. Biblical Interpretation in Ancient Israel. 3rd ed. Oxford: Clarendon, 1986. Repr. 1989.

Fleming, Democracy's Ancient Ancestors

Fleming, Daniel. Democracy's Ancient Ancestors: Mari and Early Collective Governance. Cambridge: Cambridge University Press, 2004.

Fowler, Theophoric Personal Names

Fowler, Jeaneane D. Theophoric Personal Names in Ancient Hebrew: A Comparative Study. J sotSup 49. Sheffield: јsот Press, 1988.

Fox, "The Sign of The Covenant"

Fox, Michael V. "The Sign of the Covenant: Circumcision in the Light of Priestly 'ôt Etiologies." Revue Biblique 81 (1974) 557-596.

Gaifman, Aniconism in Greek Antiquity

Gaifman, Milette. Aniconism in Greek Antiquity. Oxford Studies in Ancient Culture and Representation. Oxford and New York: Oxford University Press, 2012. 
Ganzel and Holtz, "Ezekiel's Temple"

Ganzel, Tova and Holtz, Shalom E. "Ezekiel's Temple in Babylonian Context." Vetus Testamentum 64 (2014) 211-226.

Ginsberg, The Israelian Heritage

Ginsberg, H. Louis. The Israelian Heritage of Judaism. New York: The Jewish Theological Seminary of America, 1982.

Goldstein, "Between Gods and Idols"

Goldstein, Ronnie. "Between Gods and Idols: Changes in the Attitude Towards Idol Worship in Biblical Literature, and the Revision of Isa 2:1822." Beer Sheva 18 (2005) 113-153. [Hebrew]

Goldstein, "The Composition of 2 Kings 17:7-23"

Goldstein, Ronnie. "A Suggestion Regarding the Meaning of 2 Kings 17:9 and the Composition of 2 Kings 17:7-23." Vetus Testamentum 63 (2013) 393-407.

Green, "I Undertook Great Works"

Green, Douglas J. "I Undertook Great Works": The Ideology of Domestic Achievements in West Semitic Royal Inscriptions. Forschungen zum Alten Testament II 41. Tübingen: Mohr Siebeck, 2010.

Greenberg, "Hebrew segullā: Akkadian sikiltu"

Greenberg, Moshe. "Hebrew segullā: Akkadian sikiltu." Journal of the American Oriental Society 71 (1951) 172-174.

Grosby, Biblical Ideas of Nationality

Grosby, Steve. Biblical Ideas of Nationality-Ancient and Modern. Winona Lake, Indiana: Eisenbrauns, 2002.

Haran, The Biblical Collection

Haran, Menahem. The Biblical Collection-Its Consolidation to the End of Second Temple Times and Changes of Form to the End of the Middle Ages. 3 vols. Jerusalem: Bialik and Magnes, 1996-2008. [Hebrew]

Haran, Temples and Temple-Service

Haran, Menahem. Temples and Temple-Service in Ancient Israel: An Inquiry into Biblical Cult Phenomena and the Historical Setting of the Priestly School. 2nd ed. Winona Lake, Indiana: Eisenbrauns, 1985. 
Hendel, "The Social Origins of the Aniconic Tradition"

Hendel, Ronald S. "The Social Origins of the Aniconic Tradition in Early Israel." Catholic Biblical Quarterly 50 (1988) 365-382.

Herrnstein Smith, On the Margins of Discourse

Herrnstein Smith, Barbara. On the Margins of Discourse: The Relation of Literature to Language. Chicago and London: The University of Chicago Press, 1978.

Holzinger, Exodus

Holzinger, Heinrich. Exodus. Kurzer Hand-Commentar zum Alten Testament 2. Tübingen: Mohr (Siebeck), 1900.

Houtman, Exodus

Houtman, Cornelis. Exodus. Historical Commentary on the Old Testament. 4 vols. Kampen: Kok, 1993-2002.

Huizinga, "A Definition of the Concept of History"

Huizinga, Johan. "A Definition of the Concept of History." Pages 1-10 in Philosophy \& History. Ed. R. Klibansky and H.J. Paton. Oxford: Clarendon: 1936.

Ibn Ezra

Torat Chaim Chumash. 7 vols. Ed. M.L. Katznelbogen. Jerusalem: Mossad Harav Kook, 1993. Repr. 2005. [Hebrew]

Joffe, "The Elohistic Psalter"

Joffe, Laura. "The Elohistic Psalter: What, How and Why?" Scandinavian Journal of the Old Testament 15 (2001) 142-169.

Joosten, The Verbal System

Joosten, Jan. The Verbal System of Biblical Hebrew: A New Synthesis on the Basis of Classical Prose. Jerusalem Biblical Studies 10. Jerusalem: Simor, 2012.

\section{Kamlah, Temple Building}

Kamlah, Jens, ed. Temple Building and Temple Cult. Architecture and Cultic Paraphernalia of Temples in the Levant (2.-1. Mill. B.c.E.). Proceedings of a Conference on the Occasion of the 5oth Anniversary of the Institute of Biblical Archaeology at the University of Tübingen (28-3o May 2010). Abhandlungen des Deutschen Palästina-Verneins 41. Wiesbaden: Harrassowitz, 2012. 
Keel, "Paraphernalia of Jerusalem Sanctuaries"

Keel, Othmar. "Paraphernalia of Jerusalem Sanctuaries and Their Relation to Deities Worshiped Therein during the Iron Age II A-C." Pages 317-342 in Kamlah, Temple Building. [see entry]

Knoppers, Jews and Samaritans

Knoppers, Gary N. Jews and Samaritans: The Origins and History of Their Early Relations. Oxford and New York: Oxford University Press, 2013.

Kogut, Syntax and Exegesis

Kogut, Simcha. Syntax and Exegesis: Studies in Biblical Syntax as Reflected in Traditional Jewish Exegesis. Jerusalem: Magnes, 2002. [Hebrew]

Koller, "The Semantics of לבוא"

Koller, Aaron J. "להיכנס לבוא: Synchronic and Diachronic Perspectives on the Semantics of לבוא in Ancient Hebrew." Leshonenu 75 (2103) 149-164. [Hebrew]

Koller, Semantic Field of Cutting Tools

Koller, Aaron J. The Semantic Field of Cutting Tools in Biblical Hebrew: The Interface of Philological, Semantic, and Archaeological Evidence. The Catholic Biblical Quarterly Monograph Series 49. Washington D.c.: The Catholic Biblical Association of America, 2012.

Kratz, The Composition of the Narrative Books

Kratz, Reinhard G. The Composition of the Narrative Books of the Old Testament. Trans. J. Bowden. London and New York: T \& T Clark, 2005. (Orig. pub. 2000 [German].)

Levinson, Deuteronomy

Levinson, Bernard M. Deuteronomy and the Hermeneutics of Legal Innovation. Oxford: Oxford University Press, 1997.

Levinson, "Is the Covenant Code"

Levinson, Bernard M. "Is the Covenant Code an Exilic Composition?" Pages 272-325 in In Search of Pre-exilic Israel: Proceedings of the Oxford Old Testament Seminar. Ed. John Day. London and New York: T \& T Clark, 2004. 
Lewis, "Covenant and Blood Rituals"

Lewis, Theodore J. "Covenant and Blood Rituals: Understanding Exodus 24:3-8 in Its Ancient Near Eastern Context." Pages 341-350 in Confronting the Past: Archaeological and Historical Essays on Ancient Israel in Honor of William G. Dever. Ed. J. Wright and others. Winona Lake, Indiana: Eisenbrauns, 2006.

LXX

Brooke, Alan E. and McLean, Norman. The Old Testament in Greek. 3 vols. in 9 pts. Cambridge: Cambridge University Press, 1906-1940. Repr. in 4 vols., 2009.

Machinist, "How Gods Die, Biblically and Otherwise"

Machinist, Peter. "How Gods Die, Biblically and Otherwise: A Problem of Cosmic Restructuring." Pages 189-240 in Reconsidering the Concept of Revolutionary Monotheism. Ed. B. Pongretz-Leisten. Winona Lake, Ind.: Eisenbrauns, 2011.

Manning and Morris, The Ancient Economy

Manning, J.G., and Morris, Ian, eds. The Ancient Economy: Evidence and Models. Stanford, California: Stanford University Press, 2005.

Maori, Peshitta

Maori, Yeshayahu. The Peshitta Version of the Pentateuch and Early Jewish Exegesis. Jerusalem: Magnes, 1995. [Hebrew]

Master, "Institutions of Trade"

Master, Daniel M. "Institutions of Trade in 1 and 2 Kings." Pages 501-516 in The Book of Kings: Sources, Composition, Historiography and Reception. Ed. A. Lemaire and B. Halpern. VTSup 129. Leiden: Brill, 2010.

Mek. de R. Ish.

Mechilta d'Rabbi Ismael.Ed. H.S. Horovitz and I.A. Rabin. 2nd ed. Jerusalem: Bamberger and Wahrman, 1960. [Hebrew]

Mettinger, No Graven Image

Mettinger, Tryggve N.D. No Graven Image? Israelite Ancionsim in Its Ancient Near Eastern Context. Coniectanea Biblica Old Testament Series 42. Stockholm: Almqvist \& Wiksell, 1995. 
Meyer, "Trade in Bronze Age and Iron Age Empires"

Meyer, Jørgen Christian. "Trade in Bronze Age and Iron Age Empires, A Comparison." Pages 89-106 in Ancient Economies / Modern Methodologies: Archaeology, Comparative History, Models and Institutions. Edited by Peter F. Bang and others. Bari: Edipuglia, 2006.

Mierse, Temples and Sanctuaries

Mierse, William E. Temples and Sanctuaries from the Early Iron Age Levant-Recovery After Collapse. History, Archaeology, and Culture of the Levant 4. Winona lake, Indiana: Eisenbrauns, 2012.

MT

see Dotan, BHL

Nelson, Deuteronomy

Nelson, Richard D. Deuteronomy: A Commentary. The Old Testament

Library. Louisville and London: Westminster John Knox, 2002.

Nihan, From Priestly Torah to Pentateuch

Nihan, Christophe. From Priestly Torah to Pentateuch: A Study in the Composition of the Book of Leviticus. Forschungen zum Alten Testament II 25. Tübingen: Mohr Siebeck: 2007.

Nihan, "The Torah between Samaria and Judah"

Nihan, Christophe. "The Torah between Samaria and Judah: Shechem and Gerizim in Deuteronomy and Joshua." Pages 187-223 in The Pentateuch as Torah: New Models for Understanding Its Promulgation and Acceptance. Ed. Gary N. Knoppers and Bernard M. Levinson. Winona Lake, Indiana: Eisenbrauns, 2007.

Patrick, "The Covenant Code Source"

Patrick, Dale. "The Covenant Code Source." Vetus Testamentum 27 (1977) $145^{-157}$.

Paul, Studies in the Book of the Covenant

Paul, Shalom M. Studies in the Book of the Covenant in the Light of Cuneiform Sources. VTSup 18. Leiden: Brill, 1970. Repr. Eugene, Oregon: Wipf \& Stock, 2005 . 
Ramban

Torat Chaim Chumash. 7 vols. Ed. M.L. Katznelbogen. Jerusalem: Mossad Harav Kook, 1993. Repr. 2005. [Hebrew]

Rashbam

Torat Chaim Chumash. 7 vols. Ed. M.L. Katznelbogen. Jerusalem: Mossad Harav Kook, 1993. Repr. 2005. [Hebrew]

Rashi

Torat Chaim Chumash. 7 vols. Ed. M.L. Katznelbogen. Jerusalem: Mossad Harav Kook, 1993. Repr. 2005. [Hebrew]

Rimmon-Kenan, Narrative Fiction

Rimmon-Kenan, Shlomith. Narrative Fiction: Contemporary Poetics. New Accents. New York, New York: Methuen, 1983. Repr., London: Routledge, 1989 .

Rofé, "The Blessing of Moses"

Rofé, Alexander. "The Blessing of Moses, the Temple of Nebo, and the Question of Levite Origins." Pages 409-425 in Studies in Bible and the Ancient Near East-Presented to Samuel E. Loewenstamm on His Seventieth Birthday. Ed. Yitschak Avishur and Joshua Blau. Jerusalem: E. Rubinstein, 1978. [Hebrew]

Rofé, "Ephraimite Versus Deuteronomistic History”

Rofé, Alexander. "Ephraimite Versus Deuteronomistic History," Pages 221235 in Storia e tradizioni di Israele: scritti in onore di J. Alberto Soggin. Ed. D. Garrone and F. Israel. Brescia: Paideia, 1991.

Rofé, "The Strata of the Law"

Rofé, Alexander. "The Strata of the Law about the Centralization of Worship in Deuteronomy and the History of the Deuteronomic Movement." Pages 97-101 in idem, Deuteronomy: Issues and Interpretation. Edinburgh: T \& T Clark, 2002. (Orig. pub. 1972 [Hebrew]).

Sarna, Exodus

Sarna, Nahum M. Exodus. The JPs Torah Commentary. Philadelphia, Pennsylvania: The Jewish Publication Society of America, 1991. 
Schaper, "The 'Publication' of Legal Texts"

Schaper, Joachim. "The 'Publication' of Legal Texts in Ancient Judah." Pages 225-236 in The Pentateuch as Torah: New Models for Understanding Its Promulgation and Aacceptance. Ed. Gary N. Knoppers and Bernard M. Levinson. Winona Lake, Indiana: Eisenbrauns, 2007.

Schmidt, "Israel und das Gesetz"

Schmidt, Ludwig. "Israel und das Gesetz: Ex 19,3b-8 und 24,3-8 als literarischer und theologischer Rahmen für das Bundesbuch." Zeitschrift für die alttestamentliche Wissenschaft 113 (2001) 167-185.

Schwienhorst-Schönberger, Das Bundesbuch

Schwienhorst-Schönberger, Ludger. Das Bundesbuch (Ex 20,22-23,33): Studien zu seiner Entstehung und Theologie. Beiheft zur Zeitschrift für die alttestamentliche Wissenschaft 188. Berlin and New York: Walter de Gruyter, 1990.

Segal, "The Text of the Hebrew Bible"

Segal, Michael. "The Text of the Hebrew Bible in Light of the Dead Sea Scrolls." Materia Guidaica 12 (2007) 5-20.

Sforno

Torat Chaim Chumash. 7 vols. Ed. M.L. Katznelbogen. Jerusalem: Mossad Harav Kook, 1993. Repr. 2005. [Hebrew]

Sherratt, "Mediterranean Economy"

Sherratt, Susan and Andrew. "The Growth of the Mediterranean Economy in the Early First Millennium BC." World Archaeology 24 (1993) 361-378.

Simon-Shoshan, Stories of the Law

Simon-Shoshan, Moshe. Stories of the Law: Narrative Discourse and the Construction of Authority in the Mishnah. Oxford and New York, New York: Oxford University Press, 2012.

Smith, The Early History of God

Smith, Mark S. The Early History of God: Yahweh and the Other Deities in Ancient Israel. 2nd ed. Grand Rapids, Michigan and Cambridge, U.K.: Eerdmans; Dearborn, Michigan: Dove Booksellers, 2002. 
Sommer, Bodies of God

Sommer, Benjamin D. Bodies of God and the World of Ancient Israel. Cambridge, U K and New York: Cambridge University Press, 2009.

SP

Tal, Abraham and Florentin, Moshe. The Pentateuch - The Samaritan Version and the Masoretic Version. Tel Aviv: Tel Aviv University Press, 2010. [Hebrew]

Speiser, “'People' and 'Nation' of Israel”

Speiser, E.A. “'People' and 'Nation' of Israel." Journal of Biblical Literature 79 (1960) 157-163.

Stackert, A Prophet Like Moses

Stackert, Jeffrey. A Prophet Like Moses: Prophecy, Law, and Israelite Religion.

Oxford and New York: Oxford University Press, 2014.

Stackert, Rewriting the Torah

Stackert, Jeffrey. Rewriting the Torah: Literary Revision in Deuteronomy and the Holiness Legislation. Forschungen zum Alten Testament 52. Tübingen: Mohr Siebeck, 2007.

Steiner and Killebrew, The Oxford Handbook of the Archaeology of the Levant

Steiner, Margreet L., and Killebrew, Ann E., eds. The Oxford Handbook of the Archaeology of the Levant c. 80oo-332 BCE. Oxford: Oxford University Press, 2014.

Stockton, "Phoenician Cult Stones"

Stockton, Eugene D. Australian Journal of Biblical Archaeology 2 (1974) 1-27.

Stockton, "Sacred Pillars in the Bible"

Stockton, Eugene D. Stockton, "Sacred Pillars in the Bible." Australian Biblical Review 20 (1972) 16-32.

Stockton, "Stones at Worship"

Stockton, Eugene D. "Stones at Worship." Australian Journal of Biblical Archaeology 1 (1970) 58-81.

Strauss, Persecution and the Art of Writing

Strauss, Leo. Persecution and the Art of Writing. Chicago: University of Chicago Press, 1988. (Orig. pub. 1952) 
Talmon, "The 'Desert Motif' in the Bible"

Talmon, Shemaryahu. "The 'Desert Motif' in the Bible and in Qumran Literature." Pages 216-254 in idem, Literary Studies in the Hebrew BibleForm and Content: Collected Studies. Jerusalem: Magnes; Leiden: Brill, 1993. (Orig. pub. 1966)

Talmon, "Synchroneity and Simultaneity"

Talmon, Shemaryahu. "The Presentation of Synchroneity and Simultaneity in Biblical Narrative." Pages 112-133 in idem, Literary Studies in the Hebrew Bible_Form and Content: Collected Studies. Jerusalem: Magnes; Leiden: Brill, 1993. (Orig. pub. 1978)

TDOT

Theological Dictionary of the Old Testament. Ed. G. Johannes Botterweck and others. Trans. John T. Willis. 15 vols. Grand Rapids, Michigan: Eerdmans, 1975-2006.

Tg. Frag.

Klein, Michael L. The Fragment-Targums of the Pentateuch According to Their Extant Sources. Analecta Biblica 76. 2 vols. Rome: Biblical Institute Press, 1980.

Tg. Neof.

Díez Macho, Alejandro. Neophyti 1. 6 vols. Textos y Estudios del Seminario Filológico Cardenal Cisneros 7. Madrid and Barcelona: Consejo Superior de Investigaciones Cientificas, 1968-1979.

Tg. Onq.

Sperber, Alexander. The Bible in Aramaic, Vol. 1: The Pentateuch According to Targum Onkelos. Leiden: Brill, 1959.

Tg. Ps.-Jon.

Rieder, David. Pseudo-Jonathan: Targum Jonathan Ben Uzziel on the Pentateuch. Jerusalem: Salomon, 1974.

Tg. Sam.

Tal, Abraham. The Samaritan Targum of the Pentateuch: A Critical Edition. 3 vols. Tel-Aviv: Tel-Aviv University, 1980-1983. 
Tigay, “Conflation”

Tigay, Jeffrey H. “Conflation as a Redactional Technique." Pages 53-95 in Empirical Models for Biblical Criticism. Ed. Jeffrey H. Tigay. Philadelphia: University of Pennsylvania Press, 1985. Repr. Eugene, Oregon: Wipf and Stock Publishers, 2005.

Tigay, Deuteronomy

Tigay, Jeffrey H. Deuteronomy. The JPs Torah Commentary. Philadelphia and Jerusalem: The Jewish Publication Society of America, 1996.

Tigay, "The Presence of God"

Tigay, Jeffrey H. "The Presence of God and the Coherence of Exodus 20:2226." Pages 195-211 in Sefer Moshe: The Moshe Weinfeld Jubilee VolumeStudies in the Bible and the Ancient Near East, Qumran, and Post-Biblical Judaism. Ed. C. Cohen, A. Hurvitz, and S.M. Paul. Winona Lake, Indiana: Eisenbrauns, 2004.

Tigay, You Shall Have No Other Gods

Tigay, Jeffrey T. You Shall Have No Other Gods: Israelite Religion in the Light of Hebrew Inscriptions. Harvard Semitic Studies 31. Atlanta: Scholars Press, 1986.

Tov, "Rewritten Bible Compositions"

Tov, Emanuel. "Rewritten Bible Compositions and Biblical Manuscripts, with Special Attention to the Samaritan Pentateuch." Dead Sea Discoveries 5 (1998) 334-354.

Tov, The Text-Critical Use of the Septuagint

Tov, Emanuel. The Text-Critical Use of the Septuagint in Biblical Research. 2nd ed., revised and enlarged. Jerusalem Biblical Studies 8. Jerusalem: Simor, 1997 .

Tov, Textual Criticism of the Hebrew Bible

Tov, Emanuel. Textual Criticism of the Hebrew Bible. 3 rd ed. Minneapolis: Fortress Press, 2012.

Ulrich, Biblical Qumran Scrolls

Ulrich, Eugene. The Biblical Qumran Scrolls: Transcriptions and Textual Variants. VTSup 134. Leiden: Brill, 2010. 
Weinfeld, "The Awakening of National Consciousness"

Weinfeld, Moshe. "The Awakening of National Consciousness in Israel in the Seventh Century всE." Pages 396-420 in Oz Le-David: Studies in the Bible Presented to David Ben Gurion on His Seventieth Birthday. Jerusalem: Israel Bible Society, 1964. [Hebrew]

Weinfeld, Deuteronomy and the Deuteronomic School

Weinfeld, Moshe. Deuteronomy and the Deuteronomic School. Oxford: Oxford University Press, 1972. Repr. Winona Lake, Indiana: Eisenbrauns, 1992.

Wellhausen, Prolegomena

Wellhausen, Julius. Prolegomena to the History of Ancient Israel. Trans. J. Sutherland Black and A. Menzies, Edinburgh: Adam \& Charles Black, 1885. Repr. Cleveland and New York: World Publishing, 1957, 1965. (Orig. pub. 1883 [German])

White, "The Value of Narrativity in the Representation of Reality."

White, Hayden. "The Value of Narrativity in the Representation of Reality." Critical Inquiry 7 (1980) 5-27.

Wilson, Prophecy and Society

Wilson, Robert R. Prophecy and Society in Ancient Israel. Philadelphia: Fortress, 1980. Repr. 1984.

Wright, Inventing God's Law

Wright, David P. Inventing God's Law: How the Covenant Code of the Bible Used and Revised the Laws of Hammurabi. Oxford and New York: Oxford University Press, 2009.

Zevit, "The Earthen Altar Laws"

Zevit, Ziony. "The Earthen Altar Laws of Exodus 20:24-26 and Related Sacrificial Restrictions in Their Cultural Context." Pages 53-62 in Texts, Temples, and Traditions: A Tribute to Menahem Haran. Ed. M.J. Fox and others. Winona Lake, Indiana: Eisenbrauns, 1996.

Zevit, The Religions of Ancient Israel

Zevit, Ziony. The Religions of Ancient Israel: A Synthesis of Parallactic Approaches. London and New York: Continuum, 2001. 